\title{
Structural evolution and metasomatism of subducted metaophiolites in the Northwestern Alps
}

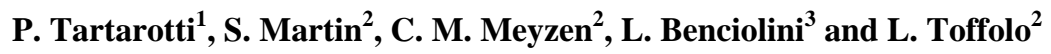

${ }^{1}$ Dipartimento di Scienze della Terra, Università degli Studi di Milano, via Mangiagalli 34 20133 Milano (Italy).

${ }^{2}$ Dipartimento di Geoscienze, Università degli Studi di Padova, via G. Gradenigo, 6 - 35131 Padova (Italy).

${ }^{3}$ Dipartimento di Chimica, Fisica e Ambiente, Università degli Studi di Udine, via del Cotonificio 114 - 3310 Udine (Italy).

Corresponding author: Paola Tartarotti (paola.tartarotti@unimi.it)

\section{Key Points:}

- The subduction complex includes serpentinites and metagabbros, flysch-type metasediments, meta-ophicarbonates, gneissic slices.

- Eclogite-facies metagabbros are associated to hybridized rocks recording $\mathrm{Ca}$ metasomatism and hydration/dehydration processes in the subduction environment.

- Structural characters constrain the timing of metasomatism between the prograde path to the HP peak 


\begin{abstract}
A subduction complex of the Northwestern Alps consists of serpentinites, eclogitic metagabbros, flysch-like metasediments, meta-ophicarbonates, and gneissic slices. Unlike other subduction complexes, it contains unusual hybridized rocks described here for the first time in the Northwestern Alps. They are preserved as patches interstitial in the metagabbro and as layers within metagabbros and serpentinites. The hybridized rocks are made of high modal zoisite/clinozoisite+white mica pseudomorphs of lawsonite, garnet, and amphibole associated with an Alpine eclogite-facies fabric. While these eclogitic metagabbros are chemically comparable to oceanic oxide gabbros from the ultraslow Southwest Indian Ridge, the layers are extremely enriched in $\mathrm{Al}_{2} \mathrm{O}_{3}$ and $\mathrm{CaO}$ and depleted in $\mathrm{TiO}_{2}, \mathrm{MgO}$, and $\mathrm{SiO}_{2}$ relative to metagabbros. Patches have a geochemical signature that is intermediate between that of layers and metagabbros. Trace element compositions of hybridized rocks suggest a contribution from a fluid derived from a mixed source made of sediments and serpentinites. Except for $\mathrm{Ba}, \mathrm{Rb}$ and $\mathrm{K}$, layers are comparable to the Global Subducting Sediments, indicating a sedimentary contribution, whereas the enrichment in $\mathrm{Cr}$ indicates a serpentinite contribution. Metasediment dehydration and chemical exchange of $\mathrm{Ca}$ and $\mathrm{Sr}$ have resulted in significant lawsonite crystallization in the subduction zone, as reflected by the ubiquitous presence of lawsonite pseudomorphs. In light of the unique textures and geochemical signature of the lawsonite pseudomorph-bearing hybridized rocks, an origin by fluid-rock interaction and Ca-metasomatism in the subduction environment is inferred and considered in the Western Alps context.
\end{abstract}

\title{
1 Introduction
}

Ophiolites represent a major component of the Mediterranean orogenic belts [e.g., Moores et al., 2000]. They have been recognized in the Alpine and Dinaride-Hellenide belts, in the Balkan peninsula, in the eastern Greece-central Turkey belts, in southern Turkey, and Cyprus. Since these ophiolites are all linked to the geodynamics of the Jurassic Tethys ocean, they have been classified as Tethyan-type ophiolites [e.g., Moores, 1982; Moores et al., 2000].

Metaophiolites in the Alpine belt are highly deformed and metamorphosed with respect to other Tethyan ophiolites. They have been interpreted as the fossil oceanic lithosphere of the western Tethys, pinched between the Penninic (palaeo-Europe) and Austroalpine (palaeo-Africa) continental domains (Figure 1) [e.g., Dewey et al., 1973; Polino et al., 1990; Deville et al., 1992]. In the Western Alps, metaophiolites occur in several tectonic units, such as the eclogitefacies Zermatt-Saas Zone [e.g., Dal Piaz, 1965; Bearth, 1967; Dal Piaz \& Ernst, 1978], the Grivola-Urtier unit [e.g., Dal Piaz et al., 2010 and references therein], the Monviso ophiolite complex [e.g., Lombardo et al., 1978; Balestro et al., 2013 and references therein], and the blueschist/greenschist-facies Combin Zone, Queyras, and Corsica ophiolite units [e.g., Vitale Brovarone et al., 2013, 2014; Lagabrielle et al., 2015 and references therein].

The study area is located in the Vallon des Eaus Rousses, which is a tributary valley of the Urtier valley (southern Aosta Valley) located inside a fossil subduction complex between the Aosta Valley and the northern flank of the Gran Paradiso massif (Figure 1). This subduction complex formed in the Late Cretaceous-Eocene [e.g., Dal Piaz et al., 2001] and consists of continental crust tectonic slices, metaophiolites, and metasediments. It records high pressure (HP) metamorphic peaks ranging between $440-550^{\circ} \mathrm{C}$, and $1.2-1.5 \mathrm{GPa}$ in continental crust slices 
(Austroalpine klippen) and in metaophiolite units [Dal Piaz et al., 2001 and references therein]. Ages of the high pressure metamorphic peaks in the subduction complex are comparable among different units, ranging between 49-40 Ma in the Austroalpine klippen and between 45-42 Ma in metaophiolites [Dal Piaz et al., 2001], and around $42 \mathrm{Ma}$ in the Penninic Gran Paradiso units [e.g., Manzotti et al., 2018]. These eclogitic peak ages differ from those revealed by metaophiolites from the northern Aosta Valley (e.g., $65 \mathrm{Ma}$ in the Valtournenche area) [Rebay et al., 2018] or in the Sesia Lanzo Zone (e.g., 79-65 Ma) [Rubatto et al., 2011], suggesting that the subducted tectonic units in this region of the Western Alps attained their maximum P-T imprint diachronously. Exhumation of the subducted metaophiolites of the Western Alps occurred in a time span ranging between ca. 42 and $36 \mathrm{Ma}$ [e.g., Reddy et al., 1999; Beltrando et al., 2009; Skora et al., 2015; Gouzu et al., 2016].

This study is focused on the following lithologies: 1) flysch-type metasediments (calcschists), meta-ophicarbonate, and chaotic metasediments associated with serpentinites enveloping eclogite-facies metagabbro bodies and boudins; 2) unique zoisite/clinozoisite+white mica-rich patches within eclogite-facies oxide metagabbros; 3) zoisite/clinozoisite+white micarich layers in contact with metagabbros, serpentinites and metasediments. In patches and layers, the zoisite/clinozoisite+white mica aggregates have a modal composition as high as $70 \%$ vol, and are interpreted as pseudomorphs replacing former lawsonite. As these rocks do not retain any textural features attributable to a certain protolith, and are here considered as hybridized rocks, the interpretation of their nature may not be unequivocal and is here discussed. Their bulk chemical composition suggests that they are strongly depleted in silica and this feature makes them distinct from differentiated igneous rocks commonly associated to ophiolites, such as trondhjemites, ruling out the possibility that our samples be metatrondhjemites as those found in nearby areas [Novo et al., 1989]. These zoisite/clinozoisite-rich rocks associated to metaophiolites are recognized and described here for the first time in the Western Alps, and represent a key-tool for understanding the geodynamic evolution of this sector of the Western Alps.

\section{Geological background}

In the Urtier valley (Aosta Valley region, NW Italy), several tectonometamorphic units have been recognized thus far [e.g., Beltrando et al., 2008] encompassing eclogite-facies metaophiolites, blueschist-facies metasediments with ophiolite olistoliths, Mesozoic carbonaticdolomitic slices (i.e., the "Faisceau de Cogne" defined by Elter, 1972), gneissic slices of Africarelated continental basement, and the northern border of the Gran Paradiso massif (Figure 1). According to Beltrando et al. [2007, 2008], the Africa-related units and metaophiolites record various Alpine deformation phases, the most recent of which is characterized by E-W trending schistosity and shear zones, these latter being correlated to the exhumation of the Gran Paradiso massif [e.g., Elter, 1971; Freeman et al., 1997; Brouwer et al., 2002; Le Bayon \& Ballevre, 2006]. In the same area, other investigators [e.g., Ellero \& Loprieno, 2017] have recently distinguished, from the top downwards (1) the Africa-related Tour Ponton klippe [e.g., Nervo and Polino, 1976] and "Acque Rosse" (i.e., Eaus Rousses) slice consisting of albite gneisses and garnet-bearing micaschists with bodies of eclogite-facies mafic rocks including the hectometric metagabbro of the Pointe Noire; (2) the underlying blueschist-facies ophiolitic Bardoney unit (made of serpentinite and metagabbro blocks embedded in a carbonate/quartz-rich or metabasic matrix) and Broillot unit (consisting of metabasites, rare serpentinites and quartzites that pass 
upwards to impure marbles and calcschists); (3) the Pene Blanche carbonatic slice, corresponding to the "Faisceau de Cogne", including a sequence of Lower Triassic metaquartzite, dolomitic marble, Liassic marble, and Liassic calcschists and marbles.

The HP metaophiolites exposed in the Urtier and nearby valleys belong to two units namely, the Zermatt-Saas and the Grivola-Urtier units [Bocchio et al., 2000; Dal Piaz et al., 2010] (Figure 2a). The Zermatt-Saas unit consists of serpentinites, metagabbros, metarodingites, mafic rocks including $\mathrm{Fe}-\mathrm{Cu}$ ore bodies, calcschists, marbles, and metaradiolarites with $\mathrm{Mn}$ mineralization [Martin \& Tartarotti, 1989; Tartarotti \& Caucia, 1993; Fontana et al., 2008; Martin et al., 2008; Panseri et al., 2008; Tumiati et al., 2015; Tartarotti et al., 2017a, 2017b]. The Grivola-Urtier unit consists of flysch-type and chaotic calcschists (including blocks and slices of mafic and gneissic rocks), metabasites, metagabbros, serpentinites and metaophicarbonates, enveloping metric to hectometric bodies of eclogite-facies metagabbros, metarodingites and chloriteschists. This unit is in tectonic contact with the underlying Gran Paradiso massif, and with the overlying Zermatt-Saas unit (Figure 1) [Dal Piaz et al., 2010]. The Grivola-Urtier unit is coupled with the gneissic Africa-related Eaus Rousses slice [Paganelli et al., 1995]. The Grivola-Urtier unit extends eastwards (see Figure 2a), i.e., towards the Champorcher and Soana valleys, where comparable metaophiolite units have been described [e.g., Battiston et al., 1984; Benciolini et al., 1984, 1988]. Along the border between the Soana and Champorcher valleys, at the Monte Nero peak, a thick slice of serpentinites includes eclogite-facies metagabbros that are associated with pods and layers of Jadeite-Quartz rich metatrondhjemite [Novo et al., 1989]. This latter rock constitutes an uncommon rock type, which has been rarely observed in the Western Alps metaophiolites.

\section{Materials and Methods}

\subsection{Adopted meso- and micro-scale techniques}

Common techniques of field mapping and structural geology were adopted in the field in order to recognize the geometry of the subduction complex in the study area and for reconstructing its tectonic evolution. Tens of thin sections were observed under the optical polarized microscope and only a minor set of them (listed in Table S1) was selected for petrographic descriptions. Electron microprobe analyses and bulk rock chemical analyses for major, minor and trace elements were performed on selected samples and reported in Tables S2S5. The technical procedures are described and reported in the Supplementary Information files. In the following, we refer to Koepke (2016) for the implemented oceanic gabbro terminology.

\subsection{Sample preparation for bulk rock chemical analyses}

The metaophiolitic complex of the study area is characterized by pronounced lithological heterogeneities expressed at the micro- to decameter-scale. Thus, an unconventional approach was taken for preparing samples before proceeding to geochemical analyses. We carefully cut with a saw strips of the white layers, and separated the patches from the metagabbro matrix in PE-metagabbros (see below), in order to ensure a representative coverage of the observed lithologic types and rock deformation character. Fifteen samples were selected for geochemical analysis whose location is indicated in Table S1. The analytical techniques employed for bulk rock analyses and sample preparation are outlined in Text S1. The geochemical results are given in Tables S4 and S5. 


\section{Geology and structure of the Vallon des Eaus Rousses}

\subsection{Field observations}

The Vallon des Eaus Rousses is a natural transect across different tectonic units pertaining to the eclogite-facies Grivola-Urtier metaophiolites, the Africa-related Eaus Rousses gneissic slice, and the Penninic Gran Paradiso nappe. Trending N-S, this valley crosses E-W trending kilometric-scale structures and geological boundaries (Figure 2). In particular, from north to south, we encounter, respectively (see Figure 2) (1) flysch-type calcschists, typically showing a regular layering defined by alternating metapelites and marbles; they also include quartz+garnet+chloritoid-rich micaschists, and minor mafic rocks; (2) antigorite+magnetite+ diopside+titanclinohumite-bearing serpentinites; (3) the "Eaus Rousses" continental sliver, composed of albite gneisses, garnet-bearing micaschists, and mafic layers preserving eclogitefacies mineral assemblages; (4) serpentinites, enveloping the main metagabbro body of the Pointe Noire (Figure 3a); these serpentinites locally include $\mathrm{cm}$ - to dm layers of chloriteschists (Figure 3b), possibly derived from marginal edges of metarodingitic dikes, as well as anastomosed shear zones of serpentine or talc; (5) the Gran Paradiso nappe, exposed in the southernmost part of the Vallon des Eaus Rousses (not shown in Figure 2) consisting of augen gneisses and granitoids representing late Variscan intrusions into a pre-Alpine basement mostly made of micaschists and amphibolites. In this area, the Gran Paradiso basement is devoid of its Mesozoic metasedimentary cover.

At Pointe Noire, along the right side of the Vallon des Eaus Rousses, serpentinites wrap a hectometer-scale body and meter to centimeter-scale boudins of eclogite-facies metagabbros, that are enveloped within the N-dipping main foliation (Figures 2, 3c, and 3d). Various types of metasedimentary breccias and chaotic calcschists are interleaved within serpentinites and eclogite bodies. They are characterized by a carbonate-rich matrix enveloping mafic or ultramafic clasts and blocks ranging in size from centimeter to meter (Figures 2 and 3e).

Eclogite-facies metagabbros retain a coarse (cm-sized) grain size, and are either not or weakly foliated (Figures 4a and 4b). At the outcrop scale, two types of eclogite-facies metagabbros were distinguished on the base of their texture. One type is an eclogite-type metagabbro (hereafter labelled as "E-metagabbro"), exhibiting the common expected HP mineral assemblage of garnet, omphacite, rutile and glaucophane (Figure $4 \mathrm{~b}$; see details in the petrography section). The second type is a patchy eclogite-type metagabbro (hereafter labelled as "PE-metagabbro") which, in addition to the common HP mineral assemblage, is characterized by the occurrence of withish, cm-sized pockets or "patches" consisting of zoisite/clinozoisite, white mica, and amphibole (Figures $4 \mathrm{c}$ and 5). These interstitial patches show curved and sinuous contacts with the minerals of the "fresh" metagabbro. The distribution of these patches is random within the metagabbro pods. As expected, no tectonic contact is observed between E- and PEmetagabbros (see "E" and "PE" portions in Figure 4c).

E-metagabbros are associated to centimeter to meter-thick and several meters-long layers of white rocks (hereafter "layers"), often covered by a rusty coating (Figures 4a, 4d, and 5; see also Figure 2). These layers are clearly transposed with the metagabbros, and their sharp contacts are parallel to the eclogitic foliation. The white layers were also found in direct contact with serpentinites or calcschists (see Figure 2). These layers consist of zoisite/clinozoisite, white mica, garnet, and amphibole. Their mineralogy is comparable to that of the white patches 
described above, but are characterized by a higher percentage of garnet visible to the naked-eye (Figure 4e). Layers may also include greenish millimeter-thick levels rich in amphibole. We focused our petrographical and geochemical study on these patches and layers.

\subsection{Structural setting}

The dominant structure in the study area is represented by a pervasive $S_{2}$ foliation (Figure 2) marked by eclogite-facies mineral assemblages partly retrogressed under blueschist- to greenschists-facies conditions. The $\mathrm{S}_{2}$ foliation is developed at the regional scale, as documented in nearby areas [e.g., Le Bayon and Ballévre, 2006; Ellero \& Loprieno, 2017]. In the metaophiolites of the Vallon des Eaus Rousses, the $S_{2}$ foliation mostly trends E-W (see Figure $2 \mathrm{a}$ and 2c) and is clearly recognizable in serpentinites, calcschists, and in more foliated metagabbros. In these latter, $S_{2}$ is defined by omphacite, garnet, rutile, and glaucophane, clearly recognizable in the field due to their coarse grain-size (Figure $4 b$ ). The $S_{2}$ foliation constitutes the axial plane of isoclinal $\mathrm{D}_{2}$ folds, that fold and transpose an earlier prograde foliation $\left(\mathrm{S}_{1}\right)$ only rarely preserved. At the outcrop scale, the $S_{1}$ foliation corresponds to the lithological contact between the zoisite/clinozoisite-rich patches (replacing former lawsonite) and the host PEmetagabbros (Figure 4c). The $S_{1}$ foliation was mostly observed at the foot of the western wall of the Pointe Noire (Figures 4a, and 4d) where it coincides with the lithological contact between layers and E-metagabbros. Inside layers, the $S_{1}$ foliation is marked by a mineral layering defined by $\mathrm{mm}$ - to $\mathrm{cm}$-thick, garnet+ zoisite/ clinozoisite-rich layers alternating with omphacite+amphibole-rich layers (Figures $4 \mathrm{f}, 6 \mathrm{a}, 6 \mathrm{~b}$, and $6 \mathrm{c}$ ). The $\mathrm{S}_{1}$ foliation is folded by $\mathrm{D}_{2}$ isoclinal or asymmetric folds, locally intrafolial, developed at the $\mathrm{cm}$ - dm-scale (Figures 6a, 6b, and 6c) and producing the $S_{2}$ axial planar foliation ("APS2" in Figure 6a). In serpentinites, $S_{1}$ coincides with the lithological contact between dm-thick chloriteschist levels and serpentinite (see Figure $3 b$ ). Further evidence of $S_{1}$ is provided by mafic metabreccias exposed in the southern Vallon des Eaus Rousses (not shown in Figure 2), where clasts still retain an internal foliation oriented at high angle to $S_{2}$ (Figure 6d). Finally, within flysch-type calcschists, more widely exposed in the nearby Champorcher and Soana valleys [e.g., Battiston et al., 1984; Tartarotti et al., 2017a, 2017b, 2019], the $\mathrm{S}_{1}$ foliation corresponds to the compositional layering typically defined by alternating metapelites and marbles, and interpreted as being the relict primary bedding.

All the $\mathrm{D}_{2}$ (and earlier) structures were in turn overprinted by $\mathrm{D}_{3}$ meter scale or larger folds characterized by $\mathrm{E}-\mathrm{W}$ trending axes and by axial planes gently dipping $\mathrm{N}$ and $\mathrm{S}$ (see Figures 3b, 6e, and 6f; see also Figures $2 \mathrm{c}$ and 2d), giving rise to interference patterns of Type 3 [Ramsay \& Huber, 1987]. The main result of the $\mathrm{D}_{3}$ phase overprinting is the rotation of the earlier structures, and their re-orientation towards a general E-W trend (Figure 2). Scattered poles of the $S_{2}$ foliation planes shown in Figure 2c are due to such reorientation. Moreover, a few $\mathrm{N}-\mathrm{S}$ trending fold axes were found and interpreted as relict (not rotated) $\mathrm{D}_{2}$ fold axes (Figure 2c). In some lithologies (e.g., in serpentinite), the $\mathrm{D}_{3}$ phase locally developed an incipient crenulation cleavage.

Ductile structures were then intersected by E-W trending faults, commonly developed along the contact between tectonic units (see Figure 2). Such faults could be related to the regional scale Aosta-Colle Joux-Ranzola Fault system (see Figure 1) [e.g., Bistacchi \& Massironi, 2000; Dal Piaz et al., 2010]. 


\section{Petrography of metagabbros and associated rocks}

\subsection{E-metagabbros and PE-metagabbros}

E-metagabbros are mostly poorly deformed, so that the original gabbroic texture and the shape of igneous minerals are still recognizable. The igneous assemblage of augite, plagioclase and Fe-Ti oxides has been replaced by the HP subduction-related mineral paragenesis consisting of coarse (mm-scale) omphacite, garnet, and rutile, and defining the well preserved eclogitefacies $S_{2}$ foliation (Figure 7). Relict $S_{1}$ foliation is documented by the occurrence of rootless isoclinal folds marked by aggregates of rutile grains (Figure 7a). In weakly foliated metagabbros omphacite ( $\mathrm{Jd}_{29-34}$; Table S2) commonly shows inclusion-rich crystal cores, and inclusion-poor rims. In some samples, fine-grained $(\leq 0,1 \mathrm{~mm})$ omphacite may occur by partial dynamic recrystallization (Figure 7a and Figure S1; Tables S1, S2; Text S1). Garnet $\left[\mathrm{Am}_{45}-\mathrm{Gr}_{37-}\right.$ $(\mathrm{Py}+\mathrm{Sp})_{18}$; Table S3] shows inclusion-rich cores and limpid rims. Thin rims of blue-green amphibole grow at the omphacite-garnet contact (Figure 7a). More foliated rocks are characterized by abundant glaucophane suggesting partial rock recrystallization under blueschistfacies conditions.

PE-metagabbros consist of two rock portions: one portion represents the typical eclogitefacies metagabbro with omphacite, garnet, and rutile; the other portion is represented by mm to $\mathrm{cm}$-sized white patches consisting of zoisite/clinozoisite-white mica aggregates, and minor amphibole, albite, quartz and titanite (Table S1). The metagabbro portion is often characterized by coarse or pegmatitic grain size (up to $\mathrm{cm}$-scale). The shape of igneous minerals is thus easily recognizable, for example the shape of augite, now pseudomorphed by omphacite (Figures $7 \mathrm{~b}$, 7c, and S1). In Figure 7b an omphacite porphyroblast shows an embayment that can be interpreted as a texture inherited from igneous augite (see Discussion). In some samples (e.g., sample AR31), the eclogite peak mineral paragenesis ("Par.1a" in Table S1) is less extensively recrystallized into fine-grained omphacite, garnet, rutile/titanite ("Par.1b" in Table S1) with respect to foliated E-metagabbros, and blueschist-facies minerals, such as glaucophane (see glaucophane replacing omphacite in Figure 7b).

\subsection{White patches and layers}

White patches in PE-metagabbros are characterized by irregular shapes and curved boundaries giving rise to curved or sinuous metagabbro-patch contacts with embayments and protrusions (Figures 7b, 7c). Patches consist of zoisite and white mica (eclogite-facies assemblage), partly recrystallized into clinozoisite, Fe-epidote, white mica, minor albite, and green amphibole (greenschists-facies assemblage; Table S1). Zoisite/clinozoisite-white mica aggregates typically show a rectangular or lozenge-like shape, reminiscent of the lawsonite crystal habit; thus we interpret the zoisite/clinozoisite-white mica aggregates as being pseudomorphs of earlier lawsonite.

The white layers are strictly associated with E-metagabbros, but also occur near the contact between metagabbros and serpentinites, as well as within serpentinites (see Figures 2 and 5). Layers are made up of a fine-grained, foliated rock consisting of zoisite, clinozoisite, Fe-epidote (altogether ranging between 20 and 70\% vol.), white mica, garnet, minor amphibole (uncoloured/pale green), carbonate, albite, quartz, and accessory rutile, coarse-grained titanite, apatite, and zircon. Sub-rectangular or lozenge-shaped aggregates of zoisite/clinozoisite+white 
mica suggest the presence of former lawsonite porphyroblasts (Figure 7d). Similar pseudomorphs of lawsonite are abundant in the calcschists near the Pointe Noire (Figure 7e), but are also ubiquitous in calcschists in the nearby valleys [Tartarotti et al., 2019].

Compared to the patches, the layers are characterized by the occurrence of millimeter scale garnet (up to $20 \%$ vol.; see Figure 4e for outcrop view), commonly including elongated microcrystals and veins of magnetite and rutile at their core (Figure S2). Garnet is chemically zoned with inclusion-rich cores rich in almandine, and rim enririched in grossular (Table S3; Figure S2). Rutile in the rock matrix is transformed into titanite which may become abundant (up to $12 \%$ vol.) in more blueschist-facies retrogressed types (e.g., sample AR27A; Table S1). Titanite may occur as idiomorphic crystals as large as 2-3 $\mathrm{mm}$. We infer that these layers are characterized by an eclogite-facies mineral paragenesis (developed in the $\mathrm{S}_{2}$ foliation) consisting of zoisite+white mica (replacing former lawsonite), garnet, and rutile, then retrogressed to blueschist/greenschist facies clinozoisite, Fe-epidote, white mica, titanite, albite and tremolite (Table S1). Green amphibole in the layers is mostly concentrated within mm-thick levels that are likely due to tectonic transposition of the adjacent metagabbro (see Figure 7f).

\subsection{Serpentinites}

Serpentinites are fine-grained rocks consisting of antigorite, magnetite, diopside, and Ticlinohumite. Serpentinites from the Pointe Noire are characterized by relict mesh texture (Figure S2a) that reveals, under the microscope, the occurrence of relict fresh olivine porphyroclasts rimmed by aggregates of fine-grained olivine neoblasts (Figure S3b). This texture is interpreted as a porphyroclastic texture typical of mantle tectonized peridotites [Mercier \& Nicolas, 1975].

\section{Bulk-rock composition of the metagabbros and associated rocks in the Vallon des Eaus Rousses}

Whole rock geochemical compositions of E- and PE-metagabbros, and of the associated white layers and patches from the Vallon des Eaus Rousses are presented in Tables S4 and S5. Detailed analytical techniques are reported in Text S1. Major, minor and trace element values are reported in Figures 8-10, where our samples are compared with published data from analogue rocks from both ophiolites and modern oceanic crust. In order to make such a comparison more congruent, we present the geochemical results by lithologies.

The E-metagabbro sample set includes, in addition to our samples, the eclogite-facies metagabbros (Fe-Ti oxides $>2 \mathrm{vol} \%$ ) sampled in the same area and published by Bocchio et al. (2000) (see also Figure 5 for sample location). The Bocchio et al. (2000)'s samples include either unretrogressed eclogite-facies metagabbro (e.g., sample U27) or retrogressed rocks under blueschist facies (e.g., samples U28, U74 and U76; Table S1). PE-metagabbros, patches and layers represent a new sample set from the Pointe Noire (see also Table S1).

\subsection{E- and PE-metagabbros}

Major element compositions of E- and PE-metagabbros are illustrated in the element$\mathrm{Al}_{2} \mathrm{O}_{3}$ variation diagrams (Figure 8). All samples are compared with both oceanic oxide gabbros [Coogan et al., 2001; Casey et al., 2007; Holm et al., 2002; Niu et al., 2002; Miller et al., 2002], 
leucogabbros [Casey et al., 2007; Miller et al., 2002], and felsic veins [Niu et al., 2002] all drilled at Ocean Drilling Program (ODP) Hole 735B, along the Southwest Indian Ridge (SWIR).

In an L.O.I. vs. $\mathrm{Al}_{2} \mathrm{O}_{3}$ diagram (Figure 8a), the E- and PE-metagabbros plot at the upper edge of the field defined by the oxide gabbros from the SWIR. In the $\mathrm{CaO}$ vs. $\mathrm{Al}_{2} \mathrm{O}_{3}$ diagram (Figure 8b), our metagabbro samples plot at the upper edge of the diagram and partly overlap the fields defined by (dioritic) felsic veins, leucogabbros, and oxide gabbros from the SWIR. The $\mathrm{SiO}_{2}$ and $\mathrm{TiO}_{2}$ contents of the Pointe Noire metagabbros fall in the fields of leucogabbros and oxide gabbros from the SWIR (Figures $8 \mathrm{c}$ and $8 \mathrm{~d}$ ).

In Figure 9, the mean trace element composition of E-metagabbros is comparable to that of the oxide gabbros from the SWIR. However, our samples are differing for having a prominent positive peak at $\mathrm{Ba}$, less marked at $\mathrm{Nb}$, a negative slope from $\mathrm{Nb}$ to $\mathrm{P}$, and low $\mathrm{Rb}$. As expected, E-metagabbros share similarities with the mean altered SWIR oceanic gabbros [Hart et al., 1999], except for an enrichment in $\mathrm{Ba}$, and to a much slighter extent in $\mathrm{Nb}$ and depletion in LREE displayed by our samples. The mean trace element composition of PE-metagabbros (see "Avg. PE-metagabbro" field in Figure 9) strongly differs from that of the SWIR oxide gabbros in having prominent peaks in $\mathrm{Ba}, \mathrm{Nb}, \mathrm{K}, \mathrm{Sr}$, and minor peaks in $\mathrm{Zr}$ and $\mathrm{Ti}$. Such element enrichment is not displayed even by the SWIR altered gabbros (Figure 9).

Geochemical results thus show that the E- and PE- metagabbros are comparable, in terms of major element chemistry, to oxide gabbros from the present-day SWIR ultra-slow spreading ridge. In terms of trace elements, both E- and PE-metagabbros are also comparable to the SWIR gabbros, except for their enrichment and stronger fractionation in $\mathrm{Ba}$ and $\mathrm{Nb}$ relative to other less incompatible elements.

\subsection{Patches and layers}

The major element compositions of patches and layers are characterized by a strong depletion in $\mathrm{SiO}_{2}\left(<45\right.$ wt. \%), and extreme enrichment in $\mathrm{Al}_{2} \mathrm{O}_{3}$ and $\mathrm{CaO}$ with respect to $\mathrm{E}$ - and PE-metagabbros, as well as to the oxide gabbros, leucogabbros, and felsic veins from the SWIR (see Table $\mathrm{S} 4$ and Figure 8). The $\mathrm{SiO}_{2}$ depletion distinguishes patches and layers from differentiated igneous rocks commonly associated to ophiolites, such as trondjhemites, ruling out the possibility that our rocks be metatrondhjemites as those found in nearby areas [Novo et al., 1989]. The white layers and patches exhibit overall higher values of L.O.I. (>1,64 wt.\%) than those of the host PE- and E-metagabbros.

When compared with other Ca-rich rocks such as epidosites and rodingites from Tonga fore-arc and Troodos and Josephine ophiolites [Richardson et al., 1987; Harper et al., 1988; Banerjee et al., 2000], patches and layers are characterized by comparable $\mathrm{CaO}$ but higher $\mathrm{Al}_{2} \mathrm{O}_{3}$ contents (Figure 8). However, patches and layers strongly differ from epidosites and rodingites for their higher LREE contents, and for their higher Sr content with respect to rodingites (Figure 9) [Evans et al., 1979, 1981]. The average pattern of patches shows a roughly higher fractionation and irregular enrichment in highly relative to moderately incompatible elements with positive peaks in $\mathrm{Ba}, \mathrm{K}$, and $\mathrm{Sr}$, as observed for PE-metagabbros.The average trace element pattern of layers is fairly different from that of a typical oxide gabbro for showing high fractionation in highly incompatible elements relative to moderate ones, with the exception 
of $\mathrm{Rb}$ and $\mathrm{K}$ (Figure 9). Their spectrum also strongly differs from the mean composition of the SWIR leucogabbros.

As lawsonite pseudomorphs are found in large amounts in the study area, their chemical composition is compared with those of rocks from other localities in the world, preserving either fresh lawsonite or its pseudomorph. Such rocks include: a) lawsonitites (up to 75 vol. \% lawsonite) and lawsonite-bearing blueschists (BLS) from Alpine Corsica (France) [Vitale Brovarone \& Beyssac, 2014; Vitale Brovarone et al., 2014]; b) BLS Franciscan complex (Coast Range, Pacheco Pass in the Diablo Range, and Western Baja Terrane) [Sadofsky \& Bebout, 2003]; c) BLS from the Catalina mélange [Bebout et al., 1999]; d) lawsonite pseudomorphbearing BLS from the Groix island [El Khor et al., 2009]. Patches and layers exhibit lower values of L.O.I. than those of lawsonitites and lawsonite-bearing BLS (Figure 8a). A peculiar feature of patches and layers is their consistently higher $\mathrm{Al}_{2} \mathrm{O}_{3}$ contents relative to most other lawsonite- or lawsonite pseudomorph-bearing BLS. In addition, patches and layers include some of the highest $\mathrm{CaO}$ wt. \% values yet found among lawsonite-bearing or lawsonite pseudomorphbearing BLS (Figure 8b). Only the lawsonitites from the Alpine Corsica yield such a $\mathrm{CaO}$ enrichment (Figure 8b; Table S4). $\mathrm{SiO}_{2}$ as well as $\mathrm{MgO}$ and $\mathrm{Na}_{2} \mathrm{O}$ (see Table S4) are systematically depleted in patches and layers relative to the lawsonite-bearing or lawsonite pseudomorph-bearing BLS (Figure 8c). These latter, together with the Corsica lawsonitites,

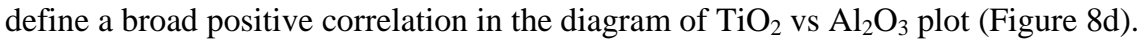

In order to compare patches and layers with other $\mathrm{Ca}-\mathrm{Al}$-rich rocks, such as sediments, their average composition was normalized to that of the Global Subducting Sediment (GLOSS), representing the mean composition of subducted sediments [Plank \& Langmuir, 1998]. GLOSSnormalized average spider diagram (Figure 10a) shows that the white layers, aside from some LILE (i.e., Rb, Ba, K and Sr), retain trace element concentrations basically indistinguishable from those of the GLOSS. White layers exhibit a mean spider diagram nearly identical to that of the Corsican lawsonitites (apart for their less extended depletion in Rb and $\mathrm{Ba}$; Figure 10a) and to the Franciscan ones which exhibit a fairly significant depletion in $\mathrm{Sr}$, but not marked negative anomalies in $\mathrm{Rb}, \mathrm{Ba}$ and $\mathrm{K}$. The mean spider diagram of patches strongly differs from that of the white layers because of an irregular pattern and a stronger depletion in highly incompatible elements relative to moderately incompatible elements. With respect to white layers, patches are enriched in $\mathrm{Rb}, \mathrm{Ba}, \mathrm{K}, \mathrm{Sr}, \mathrm{P}$ and $\mathrm{Ti}$ and depleted in $\mathrm{Th}$ and $\mathrm{Zr}$. With respect to the GLOSS, patches are strongly depleted in Th, moderately depleted in $\mathrm{Zr}$ and enriched in $\mathrm{Sr}$ and $\mathrm{P}$, Ti and $\mathrm{Eu}$.

A comparison of the mean average spider diagrams of layers and Corsican lawsonitites with that of the radiolarites and radiolarian claystones from the Jurassic sedimentary section of ODP Hole 801B in the Pacific [Vervoot et al., 2011] reveals that their fractionation patterns are extremely similar except for $\mathrm{Rb}, \mathrm{Ba}$ and $\mathrm{P}$ (Figure 10b). In addition, the average radiolarite spider diagram is overall shifted toward lower contents of trace elements relative to both white layers and Corsican lawsonitites (Figure 10b).

\section{Discussion}

7.1 Structural and microstructural constraints

The structural evolution of the Vallon des Eaus Rousses is dominated by three main Alpine ductile deformation phases and related structures. The first phase $\left(D_{1}\right)$ produced the $S_{1}$ foliation 
still preserved in patches and layers, in serpentinites, and in calcschists. This foliation corresponds to a mineral layering inside the layers, and to a lithological layering in serpentinites (e.g., alternating serpentinite-chloriteschists) and calcschists, where it is coincident with the original bedding. Within patches, the $S_{1}$ foliation corresponds to the contact between the patch and the host PE-metagabbro. Thus, this contact predates the development of the pseudomorphs of lawsonite, now consisting of zoisite/clinozoisite+white mica that coexist with the eclogitefacies PE-metagabbro. From a structural point of view, the layers are more transposed with respect to patches, being more intensely deformed during the $\mathrm{D}_{2}$ phase producing isoclinal folding of the $S_{1}$ foliation (see Figure 6).

Pseudomorphs of lawsonite are a peculiar feature of the study area, being widespread not only in patches and layers, but also in calcschists where they are associated with garnet and rutile. Although fresh lawsonite has never been documented in the study area, lawsonite pseudomorphs are widely recorded in nearby areas, as in the St. Marcel valley [e.g., Martin and Tartarotti, 1989].

The eclogite-facies mineral assemblages crystallized in metagabbros (omphacite-garnetrutile) and in layers (zoisite-garnet-rutile) define the $S_{2}$ foliation, that developed as axial planar foliation of $\mathrm{D}_{2}$ structures, mainly isoclinal folds. Accordingly, we infer that the $\mathrm{D}_{1}$ phase was prograde and developed during the Alpine subduction until the HP metamorphic peak. The second phase $\mathrm{D}_{2}$ started at the metamorphic HP peak producing the $\mathrm{S}_{2}$ foliation, and then developed during exhumation under blueschist- to greenschist facies conditions. Thus the $\mathrm{S}_{2}$ foliation is to be considered a long-lasting structure in the study area, since no subsequent foliation is developed, and survived during exhumation. The third phase $\left(\mathrm{D}_{3}\right)$ is then responsible for the kilometer scale folding and local shearing, subsequently intersected by late brittle structures.

The effect of the $\mathrm{D}_{3}$ phase is a general re-orientation of earlier fabrics towards $\mathrm{E}-\mathrm{W}$ trending structures. Since a few N-S trending fold axes attributable to $\mathrm{D}_{2}$ folds were found in the southern part of the study area (i.e., close to the Gran Paradiso massif), a regional scale reorientation of $\mathrm{D}_{2}$ structures from a N-S trend in the south, towards a E-W trend to the north, can be envisaged. E-W trending structures have been widely recognized also in nearby areas [e.g., Le Bayon and Ballevre, 2006; Beltrando et al., 2008; Ellero and Loprieno, 2017]. To the north, in the Mt. Emilus-St. Marcel area (see Figure 1 for its location), a similar re-orientation of the Alpine structures can be observed in the metaophiolites and in the Austroalpine Mt. Emilius klippe [e.g., Martin and Tartarotti, 1989; Pennacchioni, 1996], where the eclogite-facies foliation is trending N-S in the northern sectors, near the main Aosta valley, and rotates to a W-E trending in the southern sectors, near the Cogne-Urtier valleys.

In spite of this complex Alpine tectonic evolution, relict primary (i.e., pre-Alpine) features are still recognizable in the Vallon des Eaus Rousses subduction complex, namely in the poorly foliated metagabbros of the Pointe Noire. The best preserved structures shown by these metagabbros include the shape of igneous minerals, now replaced by eclogite-facies pseudomorphs, and the contacts between patches and host metagabbros. These metagabbros are enveloped by serpentinites, then the metagabbro-serpentinite pairs should have suffered a deformation partitioning [e.g., Bell, 1985] since the inception of the Alpine subduction, giving rise to low strain metagabbros wrapped by sheared serpentinites. A similar deformation partitioning effect can be envisaged in nearby areas such as the St. Marcel valley, where garnet- 
bearing glaucophanites envelope well preserved omphacite-garnet-rich boudins, [e.g., Martin and Tartarotti, 1989; Martin et al., 2008], and in the Gran Paradiso area [e.g., Manzotti et al., 2015].

\subsection{Metasomatism in patches and layers}

The white patches contain large amounts of zoisite/clinozoisite+white mica pseudomorphs of lawsonite. The enrichment in $\mathrm{Ca}, \mathrm{Al}, \mathrm{K}, \mathrm{P}, \mathrm{Rb}, \mathrm{Sr}$, LREE, Th and volatiles coupled with depletion in $\mathrm{Nb}, \mathrm{Zr}$ and $\mathrm{Ti}$ in patches relative to PE- metagabbros clearly indicates a preferential mobilization of the former elements during lawsonite crystallization [e.g., Tribuzio et al., 1996; Vitale Brovarone et al., 2014] although the mobilization of $\mathrm{Al}, \mathrm{Ca}, \mathrm{Sr}, \mathrm{Pb}$, and LREE and MREE may be also controlled by subsequent zoisite/clinozoisite crystallization [e.g., Martin et al., 2014 and references therein]. Rb, Ba and $\mathrm{K}$ are incorporated by white mica crystallization. After their formation, the geochemical signature of these patches was probably successively affected by other mineral transformations involving the breakdown of zoisite into clinozoisite. Their overall chemical similarities and the absence of metasomatic halos surrounding the patches imply that they probably crystallized from a metamorphic fluid phase that was locally in equilibrium with the host PE-type metagabbro. An inferred internal fluid control is supported by near mirrored enrichments in highly to moderately incompatible elements (Ba, K, Sr) and LREE in patches and corresponding host rocks. An external fluid control would be expected to show no dependence on the composition of the host rock.

As indicated by microstructural evidences, the formation of patches precedes the main eclogite-facies deformation stage $\mathrm{D}_{2}$ recorded by the host rock under prograde to peak metamorphic conditions. The curved shape of the patch/metagabbro contact suggests that a rockfluid interaction may have affected such rock assemblages. Prograde lawsonite crystallization is an unambiguous marker of relatively low temperatures $\left(<\sim 375^{\circ} \mathrm{C}\right)$ in very-cold subduction regimes [e.g., Zack et al., 2004; Vitale Brovarone et al., 2011]. Within the downgoing slab, fluids must have hence been transported to depth with their subducting hosts rather than migrating pervasively toward the hanging wall. Indeed, the stability of lawsonite may be enhanced by $\mathrm{CO}_{2}$ addition reaching temperatures as high as $730^{\circ} \mathrm{C}$ with $\mathrm{P}=4.2 \mathrm{GPa}$, as suggested by experimental results [e.g., Poli et al., 2009]. Lawsonite in our rocks would have been stable to P-T conditions as high as $<3 \mathrm{GPa}$ and $<700^{\circ} \mathrm{C}$, as suggested by experimental results [e.g., Poli et al., 2009; see also Martin et al., 2014 and references therein]. Accordingly, fluid-rock interactions may have been persistent to such P-T conditions.

Pseudomorphic replacement of lawsonite (as a major carrier of water bearing 11-12 wt. $\% \mathrm{H}_{2} \mathrm{O}$ ) [Martin et al., 2014] by later zoisite/clinozoisite (which is a relatively dry mineral bearing $\sim 2$ wt. $\% \mathrm{H}_{2} \mathrm{O}$ ) [Enami et al., 2004] confirms that the PE-metagabbros have also experienced a strong event of dehydration due to the breakdown of hydroxyl bearing minerals (e.g. glaucophane; lawsonite) occurring at some stage of the prograde-to-peak metamorphic evolution or during isothermal decompression.

Fluid-rock interactions with metasomatism characterized the prograde path to the HP metamorphic peak dominated by the crystallization of lawsonite and subsequent zoisite. However, fluid-rock interactions may have occurred also during the decompression path as suggested by Miller et al. [2002]. 
In the layers, the marked increase in $\mathrm{CaO}$ and $\mathrm{Sr}$ coupled with strong decreases in $\mathrm{SiO}_{2}$, $\mathrm{Rb}, \mathrm{Ba}$, and $\mathrm{K}$ probably derived from carbonate-rich lithology consumption. Addition of $\mathrm{CaO}$ and removal of $\mathrm{SiO}_{2}$ are also common during rodingitization and serpentinization at mid-ocean ridge or forearc settings [e.g. Barnes \& O’Neil, 1969; Seyfried \& Dibble, 1980; Janecky \& Seyfried, 1986; Seyfried et al., 2007; Klein et al., 2009; Honnorez \& Kirst, 1975; Iyer et al., 2008]. According to this interpretation, the eclogitic Ca-enriched Fe-Ti metagabbros from the Soana valley have been interpreted as products of metasomatism during the oceanic processes [e.g., Benciolini et al., 1984; see "Type B" metagabbros in Bocchio et al., 2000]. At present, this interpretation of the Soana valley eclogites is revised in the light of the Pointe Noire metagabbro microstructure and bulk chemical composition, and confirms the contribution of fluid-rock interactions with metasomatism during the prograde HP metamorphism. The occurrence within layers, of pseudomorphs of lawsonite and of chemically zoned garnet with Ca-rich rims also supports this metasomatism. Metarodingites were observed at the contact between metagabbros and serpentinites (see Figure 2) thus, we cannot exclude that $\mathrm{Ca}$ and $\mathrm{Al}$ transfers are mostly sourced by the destabilization of rodingite via fluid-rock interaction during downgoing transport. However, the dissolution of rodingite cannot certainly yield the high levels of enrichment in Th and LREE observed in white layers, as rodingites are intrinsically strongly depleted in these elements (see Figure 10b) [e.g., Evans, 1981].

Another unexpected geochemical feature of the layers is that most chemical elements traditionally considered as low-solubility elements ( $\mathrm{Al}, \mathrm{Zr}, \mathrm{Nb}, \mathrm{Ti}$, and $\mathrm{Cr}$; see Table $\mathrm{S} 1$ ) are mobilized showing either increase or depletion relative to the adjacent metagabbros. As such, they do not demonstrate a conservative behavior, due to a possible enhanced solubility of these elements, mostly $\mathrm{Al}_{2} \mathrm{O}_{3}$ and $\mathrm{HFSE}$ (e.g., $\mathrm{Zr}$ ) by formation of complex aluminosilicate-based polymers in HP fluids [Antignano \& Manning, 2008; Spandler \& Pirard, 2013]. Titanite crystallization may account for higher $\mathrm{Cr}$ and $\mathrm{Nb}$ contents [e.g., Prowatke \& Klemme, 2005; El Khor et al., 2009]; epidote crystallization may contribute to the $\mathrm{Cr}$ uptake [Brunsmann et al., 2000]. The enrichment in $\mathrm{Cr}$ in the white layers (see sample AR15 in Table S4) clearly points out a contribution from a fluid derived from a serpentinite source [e.g., Spandler et al., 2011]. The dissemination of zircon in layers accounts for the enrichment in $\mathrm{Zr}$ within in layers (see Table S1).

As serpentinites have on average extremely low $\mathrm{Sr}$ content $(\sim 6 \mathrm{ppm})$, we infer that serpentinite-derived fluids could not constitute a major source of $\mathrm{Sr}$. The same for the $\mathrm{Al}_{2} \mathrm{O}_{3}$ enrichment, for which a composite origin from clays, rodingite and epidosite sources seems to be more reasonable.

The chemical resemblance in terms of trace elements between our layers, metasomatic lawsonitites and GLOSS [Plank \& Langmuir, 1998] strongly supports the hypothesis that the white layers formed at the expense of original metagabbros with a significant contribution from sedimentary rocks. The distribution of most trace elements in the layers is controlled by the release of HP fluids derived from nearby metasedimentary rocks. This is also further confirmed by the negative Ce anomaly found in one sample (AR12A; see Table S5), a feature inherited from seawater interaction commonly found in slow accumulating sediments such as clays [Plank \& Langmuir, 1998]. The average spider diagram of layers is almost parallel to that of radiolarite and radiolarian clay deposits of the Mariana trench, but the latter is characterized by lower trace element contents and no $\mathrm{Rb}, \mathrm{Ba}$ and $\mathrm{K}$ depletion.

7.3 Metasomatism and fluid circulation in the subduction zone 
Our structural and geochemical results confirm that patches and layers were lawsonitebearing rocks. A significant amount of water was thus required for the formation of massive lawsonite crystallization during the prograde metamorphism along the $S_{1}$ foliation. Water or aqueous fluids likely derived from rocks incoming the subduction zone. The most important carriers of water were: GLOSS ( $7 \mathrm{wt} \%$ water) [Plank \& Langmuir, 1998], dehydrating at shallower levels $(\sim 50 \mathrm{~km})$; altered oceanic crust ( $2.7 \mathrm{wt} \%$ water) [Rüpke et al., 2004 and references therein] dehydrating between $\sim 100$ and $200 \mathrm{~km}$, and serpentinites $(\sim 12 \mathrm{wt} \%$ water $)$ [Schmidt \& Poli, 1998] between 120-200 km [Rüpke et al., 2004]. The GLOSS-normalized spider diagrams indicate that the layers retain trace element concentrations indistinguishable from those of GLOSS, confirming a significant GLOSS contribution.

Based on natural and experimental evidence, serpentinite dehydration occurs at variable high pressure and temperature conditions, depending on the subducting slab age and geothermal setting (overall, between $500^{\circ}-720^{\circ} \mathrm{C}$ and 2 - 6 GPa) [e.g., Evans, 1976; Schmidt \& Poli, 1998; Rüpke et al., 2004 and references therein]. The geochemical signature of patches and layers confirms the important contribution of serpentinite as a source for the fluids. We therefore postulate that the fluids reacting with metagabbros had a mixed composition being derived from both serpentinites and metasediments.

Dehydration process at the expense of lawsonite at the HP metamorphic peak or during the early stages of exhumation, during zoisite crystallization, induced poor or insignificant chemical transfer between patches and the host metagabbro, as suggested by the conservation of $\mathrm{Ca}, \mathrm{Al}, \mathrm{Sr}$, LREE within zoisite, and $\mathrm{Rb}, \mathrm{Ba}, \mathrm{K}$ in white mica, both replacing lawsonite. In other words, the release of fluids has not leached a significant amount of trace elements, which remained trapped in the new zoisite-bearing overprinting mineral assemblage.

Lawsonite-bearing rocks, such as the Corsica lawsonitites have been interpreted as products of prograde metasomatism at the expense of both continental rocks and metasediments [Martin et al., 2014; Vitale Brovarone et al., 2011, 2014]. Other occurrences of lawsonite metasomatites have been reported in Guatemala, within a serpentinite mélange [Tsujimori \& Ernst, 2014] and in Turkey, within HP terranes at the contact between serpentinites and metabasalts [Zack, 2013].

\subsection{Geodynamic implications}

The rock assemblage observed in the Vallon des Eaus Rousses subduction complex is reminiscent of a oceanic lithosphere accreted at a slow spreading ridge, where lithological contrasts are much greater than in a typical fast spreading, "layer-cake" mafic crust [Dilek et al., 1998 and reference therein]. The studied metaophiolites could be ascribed to a magma-poor setting, as a slow-spreading ridge or ridge-transform intersection, where sub-oceanic mantle peridotites with gabbros are exhumed to the surface and exposed on the seafloor during seafloor spreading, and then covered by ophicarbonate breccias (Figure 11a). Inside the subduction complex, no evidence of metaradiolarite was recorded in the studied area. Oceanic sediments were represented only by ophicarbonates, whereas flysch- and mélange-type sediments accumulated in the forearc and/or in the trench at the junction of the convergent European and African plates [e.g., Cloos, 1984; Festa et al., 2012, 2019]. 
All lithologies of the Vallon des Eaus Rousses are characterized by a common, pervasive eclogite-facies fabric identified as the $\left(\mathrm{S}_{2}\right)$ regional foliation. Boudinage of metagabbro pods englobed by serpentinites was coeval with the development of this fabric.This evidence suggests that the ophiolitic rocks of the Vallon des Eaus Rousses, together with metasediments and continental gneissic slivers were coupled at least since the beginning of the subduction process, giving rise to a subduction complex or tectonic mélange (Figure 11b). During exhumation, the HP fabrics were overprinted by open folds and large-scale structures, then cut by late-stage faults giving rise to the present setting characterized by tectonic mixing.

Mixing of carbonate-rich, ultramafic, and mafic rocks within the subduction zone promoted fluids/rock interactions during hydration (i.e., lawsonite formation in patches and layers) and dehydration (zoisite formation) processes (Figure 11b and 11c). Structural and geochemical results clearly highlight the prograde fluid/rock interactions formed in a cold subduction zone. Along the subduction zone slab-mantle interface, fluid flows affecting the ultramafic, mafic and sedimentary protoliths acted as agents of mass transfer to balance chemical gradients between these formations, and in our case resulted in a new bulk mixed composition.

Fluid imprint variation exists at a wide range of scales, from millimeter-scale in patches, to decameter-scale in layers. Patch formation in the PE-metagabbros might result from smallscale fluid focusing in local pockets at high pressure. At a greater scale, the composition of layers mainly depends on fluids buffering the chemical contrast between different pre-existing lithologies along their boundaries. The geochemical signature of patches and layers is dominated by a significant contribution of $\mathrm{CaO}$ and $\mathrm{Al}_{2} \mathrm{O}_{3}$ from metasediments. This process favoured the crystallization of huge amounts of lawsonite during the prograde to the eclogite-peak conditions (Figure 11c) when zoisite crystallized. Initial decompression stage is marked by (zoisite)/clinozoisite+white mica pseudomorphs replacing lawsonite in patches and layers, and glaucophane in metagabbros.

Serpentinites together with metasediments played a crucial role for supplying aqueous fluids involved in hydration reactions carrying fluid-mobile elements in the subduction system [e.g., Lafay et al., 2013; Scambelluri et al., 2016]. Consequently, the strict coupling of serpentinites and carbonaceous (meta)sediments (namely, ophicarbonate, calcschists) in the subduction environment is a powerful requirement for such geochemical transfers. This unique condition is favoured by oceanic settings dominated by serpentinites in direct contact with Carich sediments, as in slow and ultraslow spreading ridge systems.

\section{Conclusions}

- This article describes the structure, tectonic setting, and geochemical features of a peculiar subduction complex from the Western Alps metaophiolites that includes flyschtype metasediments and meta-ophicarbonate, serpentinite slivers enveloping eclogitefacies metagabbro bodies, and gneissic slices.

- Eclogite-facies metagabbros includes hybridized rocks described here for the first time in the Western Alps, occurring as either meter- to hectometer-scale layers or mm- to cmscale patches interstitial in the metagabbro matrix. 
- Patches and layers are respectively pre- to syn-tectonic with respect to the development of the HP deformation event $\left(D_{2}\right)$ which developed the regional-scale $S_{2}$ foliation. Patches and layers do not exhibit relict primary textures clearly attributable to igneous or sedimentary protoliths nevertheless, they are characterized by the persistent occurrence of rectangular aggregates of zoisite/ clinozoisite +white mica replacing lawsonite. Patches exhibit unique textural characteristics: their irregular shape and curved contacts with the host PE-metagabbro recall resorption textures and are interpreted as the effect of interaction between metagabbro and fluids within the subduction zone. The layers correspond to transposed PE-metagabbros deformed during the $\mathrm{D}_{2}$ phase.

- The eclogite-facies metagabbros are chemically comparable to oceanic oxide gabbros, leucogabbros, and dioritic felsic veins from the present-day ultra-slow South West Indian Ridge (SWIR) sampled at hole 735B.

- Patches and layers are strongly depleted in $\mathrm{SiO}_{2}$ and enriched in $\mathrm{CaO}$ and $\mathrm{Al}_{2} \mathrm{O}_{3}$, which make them distinct from typical oxide gabbros and also from trondhjemites, which typically represent the most evolved intrusive rocks in the oceanic crustal suite. They show a strong chemical similarity with orogenic HP rocks preserving fresh lawsonite from various parts of the worlds, and particularly with lawsonitites from the Alpine Corsica.

- Patches and layers are interpreted as deriving from $\mathrm{Ca}$-(lawsonite)-metasomatism triggered in the subduction environment by rock-fluid interactions. We thus infer that sediments incoming the subduction zone have played a fundamental role in the formation of such hybridized rocks.

- Hydration and dehydration processes and Ca-(lawsonite) metasomatism in the Alpine subduction environment were facilitated by the restricted coupling of serpentinites and sediments, which should reflect the main composition of the Tethyan lithosphere. Water or aqueous fluids likely derived from rocks incoming the subduction zone. The most important carriers of water were sediments (both oceanic and forearc or trench sediments), altered oceanic crust, and serpentinites.

- The subduction-related Ca-metasomatism linked to the strict association of serpentinite and Ca-rich sediments, represents a key contribution to the bulk geochemical cycle in subduction zones and mantle wedge.

\section{Acknowledgments, Samples, and Data}

Data presented in this paper, and supporting our conclusions are all original and are displayed in figures and tables. Data sources used for geochemical comparison are both reported in the text, figures and reference list. Raw data and additional files supporting our analyses and conclusions are in the Supporting Information and the Dataverse Repository (https://dataverse.unimi.it/). Grants to P.T. received from the University of Milano (PSR2018_DZANONI entitled to Dr. Davide Zanoni of the University of Milano, Department of Earth Sciences), and grants to S.M. received from the University of Padova ("ex 60\%") are acknowledged. We are grateful to the Editor of Tectonics, Laurent Jolivet for handling the manuscript during submission, and to 
unknown Associate Editor, to Besim Dragovic and one anonymous reviewer for fruitful and constructive comments and revisions of the manuscript. We thank Stefano Zanchetta for useful discussions, and Gray Bebout for providing chemical analyses of the Catalina schists. Raffaele Rispendente (Electron Microprobe technician at the Dipartimento di Scienze della Terra of the Milano University) and Daria Pasqual (Geochemical Laboratory at the Dipartimento di Geoscienze of the Padova University) are kindly thanked for their technical assistance. We are indebted to Gabriele Carugati (Insubria University, Como, Italy) for technical assistance in providing ICP analyses.

\section{References}

Antignano, A., \& Manning, C. E. (2008). Rutile solubility in $\mathrm{H} 2 \mathrm{O}, \mathrm{H} 2 \mathrm{O}-\mathrm{SiO} 2$, and $\mathrm{H} 2 \mathrm{O}-$ $\mathrm{NaA} 1 \mathrm{Si} 3 \mathrm{O} 8$ fluids at $0.7-2.0 \mathrm{GPa}$ and $700-1000{ }^{\circ} \mathrm{C}$ : Implications for mobility of nominally insoluble elements. Chemical Geology, 255, 283-293.

Balestro, G., Fioraso, G., \& Lombardo, B. (2013). Geological map of the Monviso massif (Western Alps). Journal of Maps, 9 (4). https://doi.org/10.1080/17445647.2013.842507

Banerjee, N. R., Gillis, K. M., \& Muehlenbachs, K. (2000). Discovery of epidosites in a modern oceanic setting, the Tonga forearc. Geology, 28(2), 151-154. Barnes and O'Neil, 1969.

Barnes, I., \& O'Neil, J. R. (1969). The relationship between fluids in some fresh Alpine-type ultramafics and possible modern serpentinization, Western United States. Geological Society American Bulletin, 80, 1948-1960.

Battiston, P., Benciolini, L., Dal Piaz, G.V., De Vecchi, Gp., Marchi, G., Martin, S., Polino, R., \& Tartarotti, P. (1984). Geologia di una traversa dal Gran Paradiso alla zona Sesia-Lanzo in alta val Soana, Piemonte. Memorie della Società Geologica Italiana., 9, 209 - 232.

Bearth, P. (1967). Die Ophiolithe der Zone von Zermatt-Saas Fee, Mat. Carte géologique Suisse, NS, 132.

Bebout, G. E., Ryan, J. G., Leeman, W. P., \& Bebout, A. E. (1999). Fractionation of trace elements by subduction-zone metamorphism - effect of convergent-margin thermal evolution. Earth and Planetary Science Letters, 171(1), 63-81.

Bell, T.H. (1985). Deformation partitioning and porphyroblast rotation in metamorphic rocks: a radical reinterpretation. Journal of Metamorphic Geology, 3, 109-118.

Beltrando, M., Hermann, J., Lister, G., \& Compagnoni, R. (2007). On the evolution of orogens: pressure cycles and deformation mode switches. Earth Planetary Science Letters, 256, 372388 .

Beltrando, M., Lister, G., Hermann, J., Forster, M., \& Compagnoni, R. (2008). Deformation mode switches in the Penninic units of the Urtier Valley (Western Alps): Evidence for a dynamic orogen. Journal of Structural Geology, 30, 194-219.

Beltrando, M., Lister, G., Forster, M., Dunlap, W.J., Fraser, G., \& Hermann, J. (2009). Dating microstructures by the 40Ar-39Ar step-heating technique: deformation-Pressure Temperature-time history of the Penninic Unit of the Western Alps. Lithos, 113, 801819.http://dx.doi.org/10.1016/j.lithos.2009.07.006

Benciolini, L., Martin, S. \& Tartarotti, P. (1984). Il metamorfismo eclogite-facieso nel basamento del Gran Paradiso ed in unità Piemontesi della valle di Campiglia. Memorie della Società Geologica Italiana, 9, 127 - 151. 
Benciolini, L., Lombardo, B., \& Martin, S. (1988). Mineral chemistry and Fe/Mg exchange geothermometry of Ferrogabbro-derived eclogitesfrom the Northwestern Alps. Neues Jahrbuch fur Mineralogie-Abhandlungen, 159, 199-222.

Bistacchi, A., \& Massironi, M. (2000). Post-nappe brittle tectonics and kinematic evolution of thenorthwestern Alps: an integrated approach. Tectonophysics, 327, 267-292.

Bocchio, R., Benciolini, L., Martin, S., \& Tartarotti, P. (2000). Geochemistry of eclogitised FeTi gabbros from various lithological settings (Aosta Valley ophiolites, Italian western Alps). Protolith composition and eclogite-facies paragenesis. Periodico di Mineralogia, 69, 217237.

Brouwer, F.M., Vissers, R.L.M., \& Lamb, W.M. (2002). Structure and metamorphism of the Gran Paradiso massif, Western Alps, Italy. Contribution to Mineralogy and Petrology, 143, 450-470.

Brunsmann, A., Franz, G., Erzinger, J., \& Landwher, D. (2000). Zoisite- and clinozoisitesegregations in metabasites (Tauern Window, Austria) as evidence for high-pressure fluidrock interaction. Journal of Metamorphic Geology, 18(1), 1-21.

Carignan, J., Hild, P., Mavelle, G., Morel, J., \& Yeghicheyan, D. (2001). Routine analysis of trace elements in geological samples using flow injection and low pressure on-line liquid chromatography coupled to ICP-MS: a study of geochemical references materials BR, DRN, UB-N, AN-G and GH. Geostandards and Geoanalytical Research, 25, 187-198.

Casey, J. F., Banerji, D., \& Zarian, P. (2007). Leg 179 synthesis: geochemistry, stratigraphy, and structure of gabbroic rocks drilled in ODP Hole 1105A, Southwest Indian Ridge. In J. F. Casey \& D. J. Miller (Eds.), Proceeding of the Ocean Drilling Program, Scientific Results, (Vol. 179, pp. 1-125), Ocean Drilling Program, College Station, TX. https://doi.org/10.2973/odp.proc.sr.179.001.2007.

Cloos, M. (1984). Flow mélanges and the structural evolution of accretionary wedges. Geological Society of America Special Papers, 198, 71-80.

Coogan, L. A., MacLeod, C.J., Dick, H.J.B., Edwards, S.J., Kvassnes, A., Natland, J.H., Robinson, P.T., Thompson, G., \& O'Hara, M.J. (2001). Whole-rock geochemistry of gabbros from the Southwest Indian Ridge: constraints on geochemical fractionations between the upper and lower oceanic crust and magma chamber processes at (very) slowspreading ridges. Chemical Geology, 178, 1-22.

Dal Piaz, G.V. (1965). La formazione mesozoica dei calcescisti con pietre verdi fra la Valsesia e la Valtournanche ed i suoi rapporti con il ricoprimento Monte Rosa e con la Zona SesiaLanzo. Bollettino della Società Geologica Italiana, 84, 67-104.

Dal Piaz, G.V., \& Ernst, W.G. (1978). Areal geology and petrology of eclogites and associated metabasites of the Piemonte Ophiolite Nappe, Breuil-St. Jacques area, Italian Western Alps. Tectonophysics, 51, 99-126.

Dal Piaz, G.V., Cortiana, G., Del Moro, A., Martin, S., Pennacchioni, G., \& Tartarotti, P. (2001). Tertiary age and paleostructural inferences of the eclogite-facies imprint in the Austroalpine outliers and Zermatt-Saas ophiolite, western Alps. International Journal Earth Sciences, 90, 668-684. https://doi.org/10.1007/s005310000177

Dal Piaz, G.V., Pennacchioni, G., Tartarotti, P., Carraro, F, Gianotti, F., Monopoli, B., \& Schiavo, A. (2010). Carta Geologica d'Italia, Foglio 091 Chatillon [Geological Map of Italy, sheet 091 Chatillon]. Roma ISPRA, Istituto Superiore per la Protezione e la Ricerca Ambientale. 
Deville, E., Fudral, S., Lagabrielle, Y., Marthaler, M., \& Sartori, M. (1992). From oceanic closure to continental collision: A synthesis of the "Schistes lustrés" metamorphic complex of the Western Alps. Geological Society of America Bulletin, 104, 127-139.

Dewey, J.F., Pitman, W.C. III, Ryan, W.B.F., \& Bonnin, J. (1973). Plate Tectonics and the Evolution of the Alpine System. Geological Society of America Bulletin, 84, 3137-3180.

Dilek, Y., Moores, E.M., \& Furnes, H. (1998). Structure of modern oceanic crust and ophiolites and implications for faulting and magmatism at oceanica spreading centers. In W.R. Buck, P.T. Delaney, J.A. Karson, \& Y. Lagabrielle (Eds.), Faulting and magmatism at Mid-Ocean Ridges, Geophysical Monograph Series (Vol.106, pp. 219-264). Washington, DC: American Geophysical Union.

El Korh, A., Schmidt, S. T., Ulianov, A., \& Potel, S. (2009). Trace Element Partitioning in HPLT Metamorphic Assemblages during Subduction-related Metamorphism, Ile de Groix, France: a Detailed LA-ICPMS Study. Journal of Petrology, 50(6), 1107-1148.

Ellero, A., \& Loprieno, A. (2017). Nappe stack of Piemonte-Ligurian units south of Aosta Valley: new evidence from Urtier Valley (Western Alps). Geological Journal, 1-20. https://doi.org/10.1002/gj.2984

Elter, G. (1971). Schistes lustrés et ophiolites de la zone piémontaise entre Orco et Doire Baltée (Alpes Graies) Hypothèses sur l'origine des ophiolites. Géologie Alpine, 47, 147-169.

Elter, G. (1972). Contribution a la connaissance du Briançonnais interne et de la bordure piémontaise dans les Alpes Graies nord-orientales et considérations sur les rapports entre les zones du Briançonnais et des Schistes Lustrés. Memorie dell'Istituto di Geologia e Mineralogia, Università di Padova, 28 (19 pp.).

Enami, M., Liou, J. G., \& Mattinson, C. G. (2004). Epidote Minerals in High P/T Metamorphic Terranes: Subduction Zone and High- to Ultrahigh-Pressure Metamorphism. Reviews in Mineralogy and Geochemistry, 56 (1), 347-398. https://doi.org/10.2138/gsrmg.56.1.347

Evans, B.W. (1976). Stability of chrysotile and antigorite in the serpentine multisystem. Schweitz. Mineral. Petrogr. Mitt., 56, 79-93.

Evans, B. W., Trommsdorff, V., \& Richter, W. (1979). Petrology of an eclogite-metarodingite suite at Cima di Gagnone, Ticino, Switzerland. American Mineralogist, 64, 15-31.

Evans, B. W., Trommsdorff, V., \& Goles, G. G. (1981). Geochemistry of high grade eclogites and metarodinites from the central Alps. Contributions to Mineralogy and Petrology, 76, $301-311$.

Festa, A., Dilek, Y., Pini, G.A., Codegone, G., \& Ogata, K. (2012). Mechanisms and processes of stratal disruption and mixing in the development of mélanges and broken formations: Redefining and classifying mélanges. Tectonophysics, 568-569, 7-24.

Festa, A., Pini, G.A., Ogata, K., \& Dilek, Y. (2019). Diagnostic features and field-criteria in recognition of tectonic, sedimentary and diapiric mélanges in orogenic belts and exhumed subduction-accretion complexes. Gondwana Research, 74, 7-30.

Fontana E., Panseri M., \& Tartarotti P. (2008). Oceanic relict textures in the Mount Avic serpentinites, Western Alps. Ofioliti, 33(2), 105-118.

Franz, G., \& Selverstone, J. (1992). An empirical phase diagram for the clinozoisite-zoisite transformation in the system $\mathrm{Ca}_{2} \mathrm{Al}_{3} \mathrm{Si}_{3} \mathrm{O}_{12}(\mathrm{OH})-\mathrm{Ca}_{2} \mathrm{Al}_{2} \mathrm{Fe}^{3+} \mathrm{Si}_{3} \mathrm{O}_{12}(\mathrm{OH})$. American Mineralogist, 77, 631-642.

Freeman, S.R., Inger, S., Butler, R.W.H., \& Cliff, R.A. (1997). Dating deformation using Rb-Sr in white mica: greenschist facies deformation ages from the Entrelor shear zone, Italian Alps. Tectonics, 16, 57-76. 
Gouzu, C., Yagi, K., Thanh, N. X., Itaya, T., \& Compagnoni, R. (2016). White mica K-Ar geochronology of $H P-U H P$ units in the Lago di Cignana area, western Alps, Italy: tectonic implications for exhumation. Lithos, 248-251,109-118. https://doi.org/10.1016/j.lithos.2016.01.015

Harper, G. D., Bowman, J. R., \& Kuhns, R. (1988). A field, chemical, and stable isotope study of subseafloor metamorphism of the Josephine ophiolite, California-Oregon. Journal of Geophysical Research, 93, 4625-4656.

Hart, S. R., Blusztajn, J., Dick, H. J. B., Meyer, P. S., \& Muehlenbach, K. (1999). The fingerprint of seawater circulation in a 500-meter section of ocean crust gabbros. Geochimica et Cosmochimica Acta, 63(23/24), 4059-4080.

Holm, P. M. (2002). Sr, Nd and Pb isotopic composition of in situ lower crust at the Southwest Indian Ridge: results from ODP Leg 176. Chemical Geology, 184, 195-216.

Honnorez, J., \& Kirst, P. (1975). Petrology of rodingites from the equatorial Mid-Atlantic fracture zones and their geotectonic significance. Contributions to Mineralogy and Petrology, 49, 233-257.

Iyer, K., Austrheim, H., John, T., \& Jamtveit, B. (2008). Serpentinization of the oceanic lithosphere and some geochemical consequences: constraints from the Leka Ophiolite complex, Norway. Chemical Geology, 249(1-2), 66-90.

Janecky, D. R., \& Seyfried, W. E. J. (1986). Hydrothermal serpentinization of peridotite within the oceanic crust: experimental investigations of mineralogy and major element chemistry. Geochimica et Cosmochimica Acta, 50, 1357-1378.

Klein, F., Bach, W., Jons, N., McCollom, T., Moskowitz, B., \& Berquo, T. (2009). Iron partitioning and hydrogen generation during serpentinization of abyssal peridotites from $15^{\circ} \mathrm{N}$ on the Mid-Atlantic Ridge. Geochimica et Cosmochimica Acta, 73(22), 6868-6893.

Koepke, J. (2016). Gabbro. In J. Harff et elii (Eds), Encyclopedia of Marine Geosciences, Springer Science+Business Media, Dordrecht. https://doi:10.1007/978-94-007-6238-1.

Lafay, R., Deschamps, F., Schwartz, S., Guillot, S., Godard, M., Debret, B., \& Nicollet, C. (2013). High-pressure serpentinites, a trap-and-release system controlled by metamorphic conditions: Example from the Piedmont zone of the western Alps. Chemical Geology, 343, 38-54.

Lagabrielle, Y. (2009). Mantle exhumation and lithospheric spreading: An historical perspective from investigations in the Oceans and in the Alps-Apennines ophiolites. Italian Journal of Geosciences, 128, 279-293.

Lagabrielle, Y., Vitale Brovarone, A., \& Ildefonse, B. (2015). Fossil oceanic core complexes recognized in the blueschist metaophiolites of Western Alps and Corsica. Earth Science Reviews, 141, 1-26.

Le Bayon, B. \& Ballèvre, M. (2006). Deformation history of a subducted continental crust (Gran Paradiso, Western Alps): continuing crustal shortening during exhumation. Journal of Structural Geology, 28, 793-815.

Lombardo, B., Nervo, R., Compagnoni, R., Messiga, B., Kienast, J.-R., Mével, C., Fiora, L., Piccardo, G., \& Lanza, R. (1978). Osservazioni preliminari sule ofioliti metamorfiche del Monviso (Alpi Occidentali). Rendiconti della Società Geologica Italiana di Mineralogia e Petrologia, 34, 253-305.

Manzotti, P., Bosse, V., Pitra, P., Robyr, M., Schiavi, F., \& Ballèvre, M. (2018). Exhumation rates in the Gran Paradiso Massif (Western Alps) constrained by in situ U-Th-Pb dating of 
accessory phases (monazite, allanite and xenotime). Contribution to Mineralogy and Petrology, 173(24). https://doi.org/10.1007/s0041 0-018-1452-7

Martin, L. A. J., Hermann, J., Gauthiez-Putallaz, L., Whitney, D. L., Vitale Brovarone, A., Fornash, K. F., \& Evans, N. J. (2014). Lawsonite geochemistry and stability - implication for trace element and water cycles in subduction zones. Journal of Metamorphic Petrology, 32, 455-478.

Martin, S., \& Tartarotti, P. (1989). Polyphase HP metamorphism in the ophiolitic glaucophanites of the lower St. Marcel Valley (Aosta, Italy). Ofioliti, 14, 135-156.

Martin, S., Rebay, G., Kienast, J.-R., \& Mével., C. (2008). An eclogitised oceanic palaeohydrothermal field from the St. Marcel Valley (Italian Western Alps). Ofioliti, 33 (1), 49-63.

Mercier, J.-C.C., \& Nicolas, A. (1975). Textures and fabrics of upper mantle peridotites as illustrated by xenoliths from basalts. Journal of Petrology, 16, 454-487.

Miller, D. J., \& Cervantes, P. (2002). Sulfide mineral chemistry and petrography and platinum group element composition in gabbroic rocks from the Southwest Indian Ridge. In J. H. Natland, H. J. B. Dick, D. J. Miller \& R. P. Von Herzen, Proceeding of the ODP, Sci. Results (Vol. 176, pp. 1-29). College Station, TX: Ocean Drilling Program.

Moores, E. M. (1982). Origin and emplacement of ophiolites. Reviews of Geophysics and Space Physics, 20, 735-760.

Moores, E. M., Kellogg, L. H., \& Dilek, Y. (2000). Tethyan ohpiolites, mantle convection, and tectonic "historical contingency": A resolution of the "ophiolite conundrum". In Y. Dilek, E. Moores, D. Elthon, A. Nicolas (Eds.), Ophiolites and oceanic crust: new insights from field studies and the Ocean Drilling Program, Special Paper (Vol. 349, pp. 3-12). Boulder, CO: Geological Society of America.

Nervo, R. \& Polino, R. (1976). Un lembo di cristallino Dent Blanche alla Torre Ponton (Valle d'Aosta). Boll. Soc. Geol. It., 96, 647-657.

Niu, Y., Gilmore, T., Mackie, S., Greig, A., \& Bach, W. (2002). Mineral chemistry, whole-rock compositions, and petrogenesis of Leg 176 gabbros: data and discussion. In J. H. Natland, H. J. B. Dick, D. J. Miller, R. P. Von Herzen (Eds.), Proceedings of the Ocean Drilling Program, Science Research, (Vol 176, pp. 1-60). College Station, TX: Ocean Drilling Program.

Novo, M., Accotto, S., Nervo, R., \& Pognante, U. (1989). Jadeite-quartz bearing metatrondhjemites from the Mt. Nero ophiolitic eclogites, Champorcher Valley (NorthWestern Alps). Ofioliti, 14 (1/2), 57-62.

Paganelli, E., Compagnoni, R., Nervo, R., \& Tallone S. (1995). Il lembo Austroalpino di Eaux Rousses e le sue relazioni con la Zona Ofiolitica Piemontese nell'alta Valle di Cogne, Valle d'Aosta meridionale. In R. Polino, R. Sacchi (Eds.), Atti convegno Alpi-Appennino, Peveragno (Vol. 14, pp. 335-348). Accademia Nazionale dei XL: Roma.

Panseri M., Fontana E., \& Tartarotti P. (2008). Evolution of rodingitic dykes: metasomatism and metamorphism in the Mount Avic serpentinites (Alpine Ophiolites, Southern Aosta Valley). Ofioliti, 33(2), 161-181.

Pennacchioni, G. (1996). Progressive eclogitization under fluid-present conditions of pre-Alpine mafic granulites in the Austroalpine Mt Emilius Klippe (Italian Western Alps). Journal of Structural Geology, 18, 549-561. https://doi.org/10.1016/S0191-8141(96)80023-X.

Plank, T., \& Langmuir, C. H. (1998). The chemical composition of subducting sediment and its consequences for the crust and mantle. Chemical Geology, 145, 325-394. 
Poli, S., Franzolin, E., Fumagalli, P., \& Crottini, A. (2009). The transport of carbon and hydrogen in subducted oceanic crust: An experimental study to 5 GPa. Earth and Planetary Science Letters, 278, 350-360.

Polino, R., Dal Piaz, G.V., \& Gosso, G. (1990). Tectonic erosion at the Adria margin and accretionary processes for the Cretaceous orogeny of the Alps. Mémoire de la Société Géologique de France, 156, 345-367.

Prowatke, S. \& Klemme, S. (2005). Effect of melt composition on the partitioning of trace elements between titanite and silicate melt. Geochimica and Cosmochimica Acta, 69, 695709.

Ramberg, H. (1964). Selective buckling of composite layers with contrasted rheological properties, a theory for the simultaneous formation of several orders of folds. Tectonophysics, 1, 307-341.

Ramsay, J. G., \& Huber, M. I. (1987). The techniques of modern structural geology. (Vol. 2): Folds and Fractures. London, UK: Academic Press, pp. 703.

Rebay, G., Zanoni, D., Langone, A., Luoni, P., Tiepolo, M., \& Spalla, M. I. (2018). Dating of ultramafic rocks from the Western Alps ophiolites discloses Late Cretaceous subduction ages in the Zermatt-Saas Zone. Geological Magazine, 155(2), 298-315. https://doi.org/10.1017/S0016756817000334

Reddy, S. M., Wheeler, J., \& Cliff, R.A. (1999). The geometry and timing of orogenic extension: an example from the Western Italian Alps. Journal of Metamorphic Geology, 17, 573-589.

Richardson, C. J., Cann, J. R., Richards, H. G., \& Cowan, J. G. (1987). Metal-depleted root zones of the Troodos ore-forming hydrothermal systems, Cyprus. Earth and Planetary Science Letters, 84, 243-253.

Rubatto, D., Regis, D., Hermann, J., Boston, K., Engi, M., Beltrando, M., et al. (2011). Yo-yo subduction recorded by accessory minerals in the Italian Western Alps. Nature geoscience. https://doi.org/10.1038/NGEO1124

Rüpke, L.H., Phipps Morgan, J., Hort, M., Connolly, J.A.D. (2004). Serpentine and the subduction zone water cycle. Earth and Planetary Science Letters, 223, 17-34.

Sadofsky, S. J., \& Bebout, G. E. (2003). Record of forearc devolatilization in low -T, high -P/T metasedimentary suites: Significance for models of convergent margin chemical cycling. Geochemistry Geophysics Geosystems, 4(4), 9003. https://doi.org/10.1029/2002GC000412

Scambelluri, M., Bebout, G. E., Belmonte, D., Gilio, M., Campomenosi, N., Collins, N., \& Crispini, L. (2016). Carbonation of subduction-zone serpentinite (high-pressure ophicarbonate; Ligurian Western Alps) and implications for the deep carbon cycle. Earth and Planetary Science and Letters, 441, 155-166.

Schmidt, M. \& Poli, S. (1998). Experimentally based water budgets for dehydrating slabs and consequences for arc magma generation. Earth and Planetary Science and Letters, 163, 361379.

Selverstone, J., Franz, G., Thomas, S. \& Getty, S. (1992). Fluid variability in 2 GPa eclogites as an indicator of fluid behavior during subduction. Contribution to MIneralogy and Petrology, 112, 341-357.

Seyfried, W. E., \& Dibble, W. E. J. (1980). Sea water-peridotite interaction at $300^{\circ} \mathrm{C}$ and 500 bars: implications for the origin of oceanic serpentinites. Geochimica et Cosmochimica Acta, 44, 309-321.

Seyfried, W. E. J., Foustoukos, D. I. \& Fu, Q. (2007). Redox evolution and mass transfer during serpentinization; an experimental and theoretical study at $200^{\circ} \mathrm{C}, 500$ bar with implications 
for ultramafic-hosted hydrothermal systems at mid-ocean ridges. Geochimica et Cosmochimica Acta, 71(15), 3872-3886.

Siivola, J., \& Schmid, R. (2007). List of mineral abbreviations-Recommendations by the IUGS Subcommission on the Systematics of Metamorphic Rocks: 12. Web version 01.02.07.

Skora S., Mahlen, N.J., Johnson, C.M., Baumgartner, L.P., Lapen, T.J., Beard, B.L., \& Szilvagyi, E.T. (2015). Evidence for protracted prograde metamorphism followed by rapid exhumation of the Zermatt-Saas Fee ophiolite. Journal of Metamorphic Geology, 33, 711-734. https://doi.org/10.1111/jmg.12148

Spandler, C., Pettke, T. \& Rubatto, D., 2011. Internal and external fluid sources for eclogitefacies veins in the Monviso meta-ophiolite, Western Alps: implications for fluid flow in subduction zones. Journal of Petrology, 52, 1207-1236. https://doi.org/10.1093/petrology/egr025

Spandler, C., \& Pirard, C. (2013). Element recycling from subducting slabs to arc crust: A review. Lithos, 170-171, 208-223.

Tartarotti P., \& Caucia F. (1993) Coexisting cummingtonite-sodic amphibole pair in metaquartzites from the ophiolite's sedimentary cover (St. Marcel Valley, Italian Western Alps): A X-ray structure refinement and petrology study. Neues Jahr. Miner. Abh., 165, 223-243.

Tartarotti, P., Festa, A., Benciolini, L., \& Balestro, G. (2017a). Record of Jurassic mass transport processes through the orogenic cycle: Understanding chaotic rock units in the high-pressure Zermatt-Saas ophiolite (Western Alps). Lithosphere, 9(3), 399-407. https://doi.org/10.1130/L605.1

Tartarotti, P., Guerini, S., Rotondo, F., Festa, A., Balestro, G., Bebout, G.E., Cannaò, E., Epstein, G.S., \& Scambelluri, M. (2019). Superposed sedimentary and tectonic block-in-matrix fabrics in a subducted serpentinite mélange (high-pressure Zermatt Saas Ophiolite, Western Alps). Geosciences, 9, 358. https://doi:10.3390/geosciences9080358

Tartarotti, P., Martin, S., Monopoli, B., Benciolini, L., Schiavo, A., Campana, R., \& Vigni, I. (2017b). Geology of the Saint-Marcel valley metaophiolites (Northwestern Alps, Italy). Journal of Maps, 13(2), 707-717. http://dx.doi.org/10.1080/17445647.2017.1355853.

Tribuzio, R., Messiga, B., Vannucci, R., \& Bottazzi, P. (1996). Rare earth element redistribution during high-pressure-low-temperature metamorphism in ophiolitic $\mathrm{Fe}$-gabbros (Liguria, northwestern Italy): Implications for light REE mobility in subduction zones. Geology, 24, 711-714.

Tsujimori, T. \& Ernst, W.G. (2014). Lawsonite blueschists and lawsonite eclogites as proxies for palaeo-subduction zone processes: a review. Journal of Metamorphic Geology, 32, 437-454.

Tumiati, S., Godard, G., Martin, S., Malaspina, N., \& Poli, S. (2015). Ultra-oxidized rocks in subduction mélanges? Decoupling between oxygen fugacity and oxygen availability in a Mn-rich metasomatic environment. Lithos, 226, 116-130. http://dx.doi.org/10.1016/j.lithos.2014.12.008

Vervoot, J. D., Plank, T., \& Prytulak, J. (2011). The Hf-Nd isotopic composition of marine sediments. Geochimica and Cosmochimica Acta, 75, 5903-5926.

Vitale Brovarone, A., \& Beyssac, O. (2014). Lawsonite metasomatism: A new route for water to the deep Earth. Earth and Planetary Science and Letters, 393, 275-284. http://dx.doi.org/10.1016/j.epsl.2014.03.001 
Vitale Brovarone, A., \& Herwartz, D. (2013). Timing of HP metamorphismin the Schistes Lustrés of Alpine Corsica: new Lu-Hf garnet and lawsonite ages. Lithos, 172-173, 175-191. https://doi.org/10.1016/j.lithos.2013.03.009

Vitale Brovarone, A., Beltrando, M., Malavieille, J. et al. (2011). Inherited Ocean-Continent Transition zones in deeply subducted terranes: insights from Alpine Corsica. Lithos, 124, 273-290. https://doi.org/10.1016/j.lithos.2011.02.013

Vitale Brovarone, A., Alard, O., Beyssac, O., Martin, L., \& Picatto., M. (2014). Lawsonite metasomatism and trace element recycling in subduction zones. Journal of Metamorphic Geology, 32, 489-514. https://doi.org/10.1111/jmg.12074

Zack, T. A. (2013). Cold slab-mantle interface: constraints from exceptionally well preserved lawsonite eclogites. Mineralogical Magazine, 77, 2574.

Zack, T. A., Rivers, T., Brumm, R., \& Kronz, A. (2004). Cold subduction of oceanic crust: Implications from a lawsonite eclogite from the Dominican Republic. European Journal of Mineralogy, 16(6), 909-916.

\section{Figure Captions}

Figure 1. Regional geology of the study area (modified after Tartarotti et al., 2017a). a) Geographic location of the study area within the Italian peninsula. b) Tectonic map with legend of the northwestern Alps and location of the studied area (black box). EM: Austroalpine Mt. Emilius klippe (see text).

Figure 2. Geological map and structural data of the Vallon des Eaus Rousses. a) Tectonic sketch map showing the main tectonic units, and location of the study area (redrawn after Dal Piaz et al., 2010). The dashed red line shows the inferred boundary and eastwards extension of the Grivola-Urtier (G-U) unit. b) Simplified geological map of the Vallon des Eaus Rousses. In the legend, the dark and light colors, for each lithology respectively, indicate the exposed and inferred outcrops. Star refers to the main sampling area (see the enlargement in Figure 5). c) Stereographic projections (Schmidt net, lower hemisphere) of $S_{2}$ foliation and $b_{2}$ fold axes in the metaophiolite unit. d) Stereographic projection of $S_{2}$ foliation and $b_{3}$ fold axes. e) Geologic cross section (as defined in Figure b). Question mark refers to the uncertain contact between white layers and serpentinites.

Figure 3. General view of the main lithologies encountered in the Eaus Rousses valley. a) Panoramic view (looking to the west) of the eastern side of the Eaus Rousses valley and location of the Pointe Noire peak. Serpentinites (serp), eclogite-facies oxide metagabbros (Ecl) of the metaophiolite unit, and the Africa-related Eaus Rousses unit (ER) are indicated. The Penninic Gran Paradiso massif is visible in the background. The Grivola peak (on the right) pertains to the metaophiolite domain. Dashed red line: main fault zones. b) Outcrop (polished by glacier) of serpentinites (Serp) with layers of chloriteschists $(\mathrm{Chl})$ folded by $\mathrm{D}_{3}$ folds with axial planes $\left(\mathrm{AP}_{3}\right)$ gently dipping to the north. Trace of folded $\mathrm{S}_{2}$ foliation is indicated. c) Panoramic view of the north dipping hectometer-scale body of eclogite-facies metagabbros (E) wrapped by serpentinites (Serp). d) Meter-scale boudin of eclogite-facies metagabbro enveloped by 
serpentinite. e) Metasedimentary breccias or mélange (Mé) characterized by carbonate-rich matrix and mafic and ultramafic clasts and blocks (arrow) ranging in size from centimeter to meter. Trace of $S_{2}$ foliation strike is indicated.

Figure 4. Eclogite-facies metagabbros at the Pointe Noire and associated rocks. a) General view of the Pointe Noire western wall: the pyramidal Pointe Noire peak is constituted by eclogitefacies metagabbros as shown in Figures $4 \mathrm{~b}$ and $4 \mathrm{c}$. Location of the white layer shown in Figure $4 \mathrm{~d}$ is indicated. b) View of E-metagabbro (weakly foliated type) consisting of garnet (Grt), Naclinopyroxene (Cpx), and Na- amphibole (Gln). Photo taken on a debris block. c) Photo (from a debris block) of E-metagabbro (E) in contact with "patchy" PE- metagabbro (PE). White portions correspond to patches (see text). d) View of the white layer at the bottom of the Pointe Noire western wall. e) Close-up view of a white layer. Note the widespread occurrence of garnet (brownish dots) on a white background consisting of zoisite/clinozoisite +white mica. f) Example of white layer: metamorphic layering marked by $\mathrm{mm}$ - to $\mathrm{cm}$-thick white garnet-rich layers alternating with green amphibole+epidote-rich layers. Hammer as scale.

Figure 5. Sampling area and photographies of representative samples. a) Detailed geological map of the sampling area with location of the sampling sites (1-4). Same legend as in Figure 2. b) Picture of a saw-cut sample of "patchy" PE-metagabbro (sample AR11). White patch is indicated by arrow. c) Picture of saw-cut sample of white layer (sample AR12). d) Saw-cut sample of white layer (sample AR14A) in contact with a greenish rock (sample AR14B: see Table S1). e) Contact between white layer (boudinated) and surrounding foliated green rock in sample LB1. f) Saw-cut sample of white layer (sample AR27A) in contact with green retrogressed eclogite (sample AR27B). See also Table S1 for sample details.

Figure 6. Structural features of the studied area. a) Layers: earliest foliation visible in the field $\left(\mathrm{S}_{1}\right)$ marked by a mineral layering defined by alternating $\mathrm{mm}$ - to $\mathrm{cm}$-scale white and green layers. $S_{1}$ is folded by $D_{2}$ isoclinal folds with gently dipping axial planar $S_{2}$. b) and c) Other examples of $S_{1}$ mineral layering folded and transposed by rootles $D_{2}$ folds within white layers. d) Mafic metabreccia from the southern Eaus Rousses valley: $S_{1}$ foliation within clasts oriented at high angle to $S_{2}$. e) and f) Transposed $S_{2}$ compositional layering folded by $D_{3}$ open folds with north dipping axial planes $\left(\mathrm{F}_{3} \mathrm{AP}\right)$ and $\mathrm{E}-\mathrm{W}$ trending fold axes in the white layer at the foot of Pointe Noire wall.

Figure 7. Photomicrographs of eclogite-facies metagabbros and associated rocks. a) Emetagabbro with coarse grain-size and weakly foliated structure (sample U27). Prograde $S_{1}$ is marked by rutile crystal aggregates folded and transposed by $D_{2}$ isoclinal folds; eclogite-facies $S_{2}$ trajectory is indicated by hatched white line. "Ompc": coarse-grained omphacite; "Ompf": finegrained omphacite. Green amphibole (Amp) grows along the garnet/omphacite contact. Plane polarized light. b) Pegmatoid PE-metagabbro with cm-scale omphacite pseudomorph after original augite, and in turn replaced by glaucophane + ankerite (brown crystals). Arrow points to the embayment in the omphacite megacryst (sample AR31; plane polarized light). c) PEmetagabbro ("PE-mgb") with coarse-grained omphacite replaced by uralite symplectites (sympl.) and partly recrystallized into fine-grained omphacite. Hatched white line underlines the contact $\left(\mathrm{S}_{1}\right)$ between metagabbro and patch consisting of zoisite/clinozoisite +white mica (sample AR11). Plane polarized light. d) Zoisite/clinozoiste+white mica aggregates replacing former 
rectangular crystals of lawsonite (Lws pseudom.) and garnet (Grt) in a white layer (sample AR14); crossed polar. e) Zoisite/clinozoiste+white mica aggregate replacing former lozengeshaped lawsonite in calcschist (sample AR20); crossed polar. f) Amphibole+titanite-rich aggregates transposed within white layer (sample AR12); plane polarized light.

Figure 8. Variations in selected major elements (in Wt.\%) and Loss On Ignition (LOI, in Wt. \%) as a function of $\mathrm{Al}_{2} \mathrm{O}_{3}$ for our samples compared with those displayed by oceanic oxide gabbros [after Coogan et al., 2001; Casey et al., 2007; Holm et al., 2002; Niu et al., 2002; Miller et al., 2002]; leucogabbros [after Casey et al., 2007; Miller et al., 2002]; felsic veins [after Niu et al., 2002]; lawsonitites and lawsonite-bearing blueschists (BLS) from Alpine Corsica [after Vitale Brovarone \& Beyssac, 2014; Vitale Brovarone et al., 2014]; BLS from Franciscan complex (Coast Range, Pacheco Pass in the Diablo Range, and Western Baja Terrane) [after Sadofsky \& Bebout, 2003]; BLS from the Catalina mélange [after Bebout et al., 1999]; lawsonite pseudomorph-bearing BLS from the Groix island: after El Khor et al. [2009]; epidosites [after Barnejee et al., 2000; Harper et al., 1988; Richardson et al., 1987]; rodingites [after Evans et al., 1979, 1981].

Figure 9. Trace elements composition of the rocks of this study averaged by lithologies ("Avg.") and normalized to the average of oxide gabbros drilled at site ODP Hole 735B along the Southwest Indian Ridge [Coogan et al., 2001; Holm et al., 2002; Miller et al., 2002; Niu et al., 2002; Casey et al., 2007].

Figure 10. Chemical compositions of the rocks of this study averaged by lithologies and normalized to the global subducting sediment composition (GLOSS) [Plank \& Langmuir, 1998]. Literature data for comparison as in Figure 8.

Figure 11. Conceptual model illustrating the tectonic evolution of the Vallon des Eaus Rousses metaophiolite complex during subduction (isotherms taken from Tsujimori \& Ernst, 2014). a) Oceanic setting of the Jurassic Tethys ocean. b) Prograde (blueschist- to eclogite-facies) conditions consistent with lawsonite crystallization. Hydration and fluid-rock interactions constrain the Ca-metasomatism. c) HP metamorphic peak. Dehydration and fluid-rock interactions are characterized by zoisite crystallization. Enlargements in the lower part of the figure: a) Tethys seafloor covered by pelagic sediments on top of oceanic lithosphere consisting of serpentinized mantle peridotites (dark green) and ophicarbonate (green lines) intruded by gabbros (light green pockets). b) The subduction complex start to develop including serpentinites and boudinated gabbros/metagabbros, sediment/metasedimens (oceanic: light brown; forearc: light yellow), and gneissic slices (brown); $S_{1}$ foliation developed along the lithology contacts. Patches develop by fluid-rock interactions. c) HP metamorphic peak. $\mathrm{S}_{2}$ foliation is indicated. Layers develop by tectonic transposition. White arrows: fluid/rock interactions enhanced by hydration and Ca-metasomatism. Red arrows: fluid/rock interactions accompanied by dehydration with zoisite crystallization. 
Figure 1. 


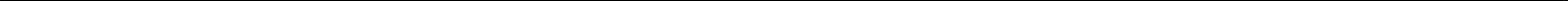


Figure 2. 
Tectonic sketch

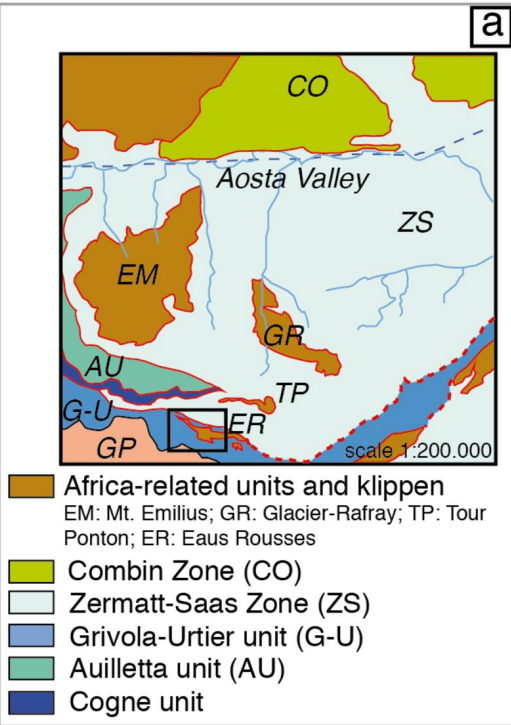

\section{Metaophiolite structural data}

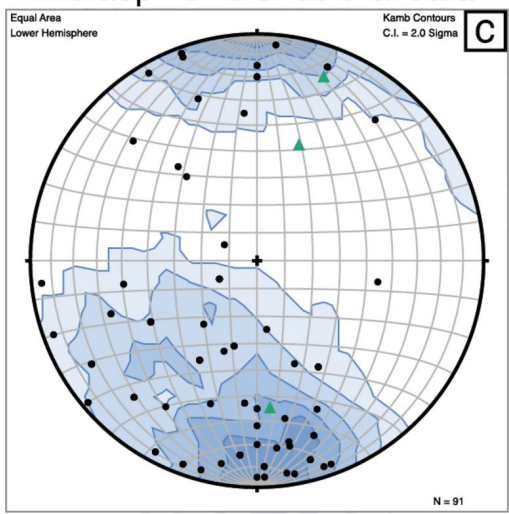

S2 foliation (poles of planes).

Contour (2\%). $n=88$

$\Delta b_{2}$ fold axis

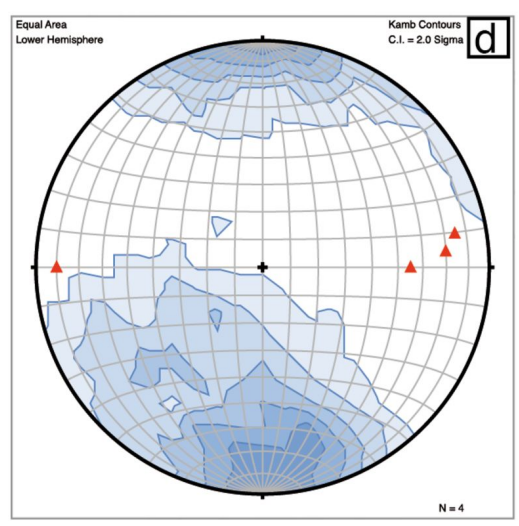

$\Delta b_{3}$ fold axis

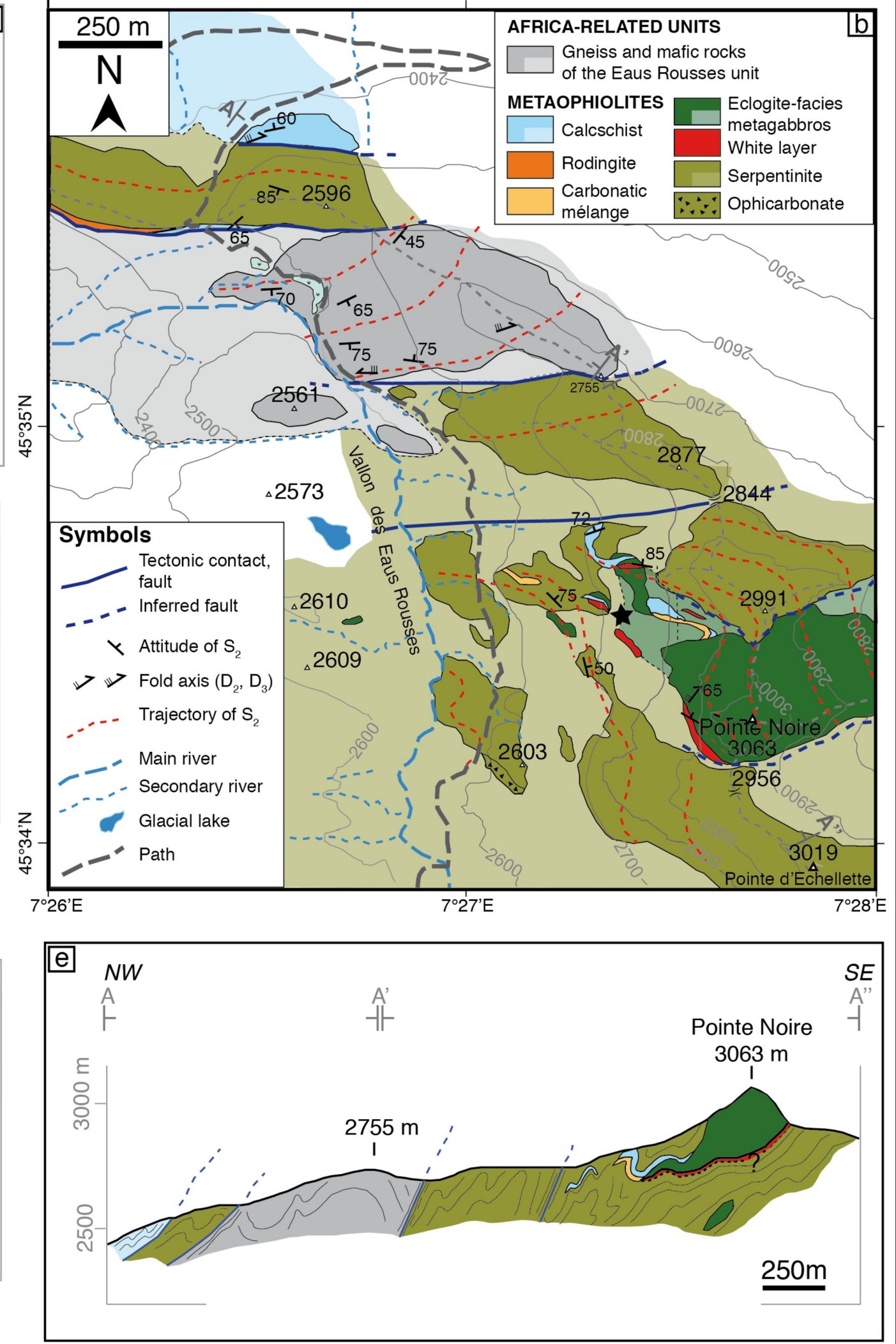


Figure 3. 


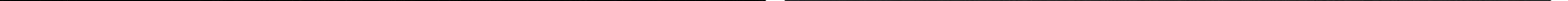


Figure 4. 
b (2)
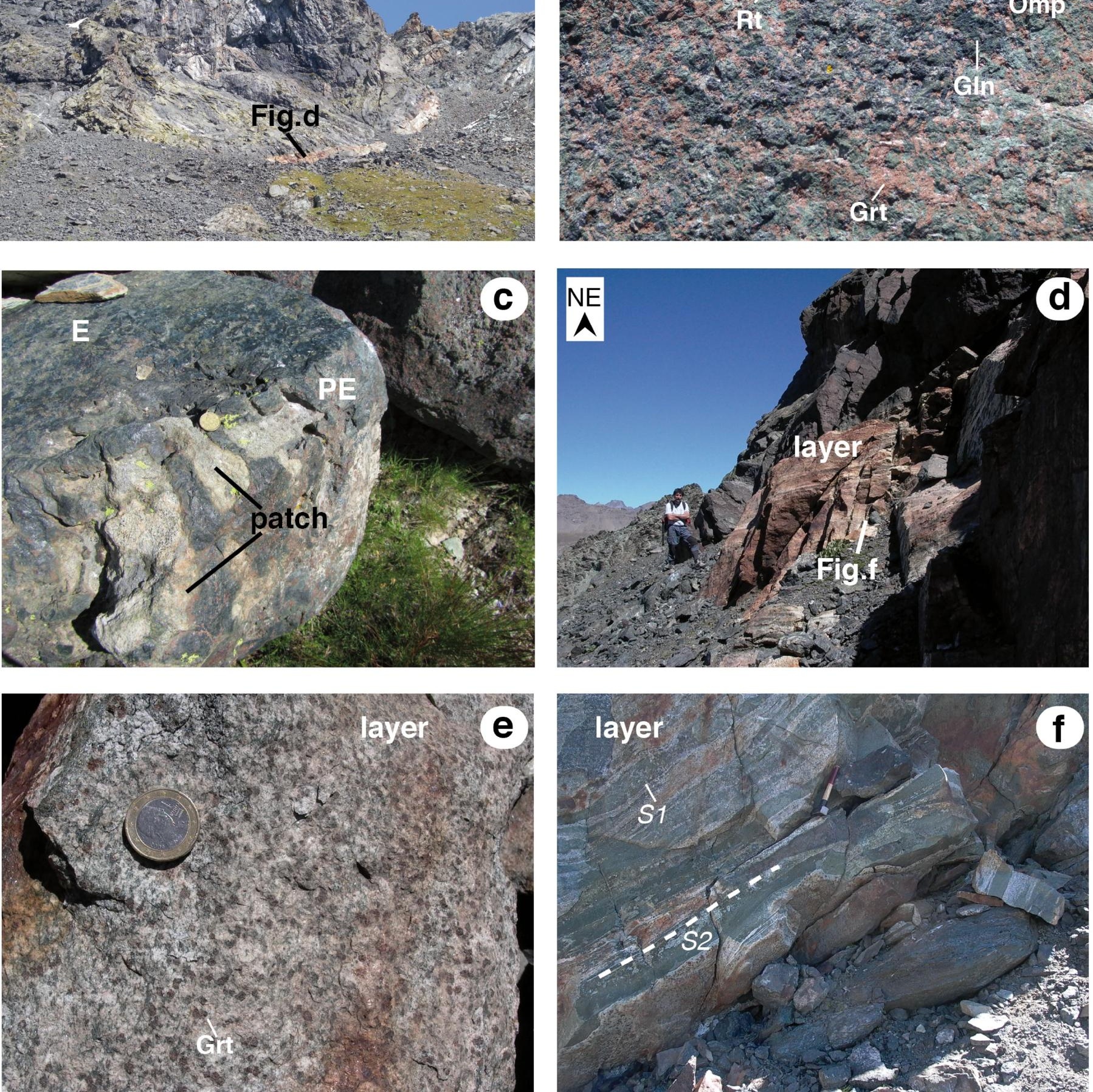

\section{layer}
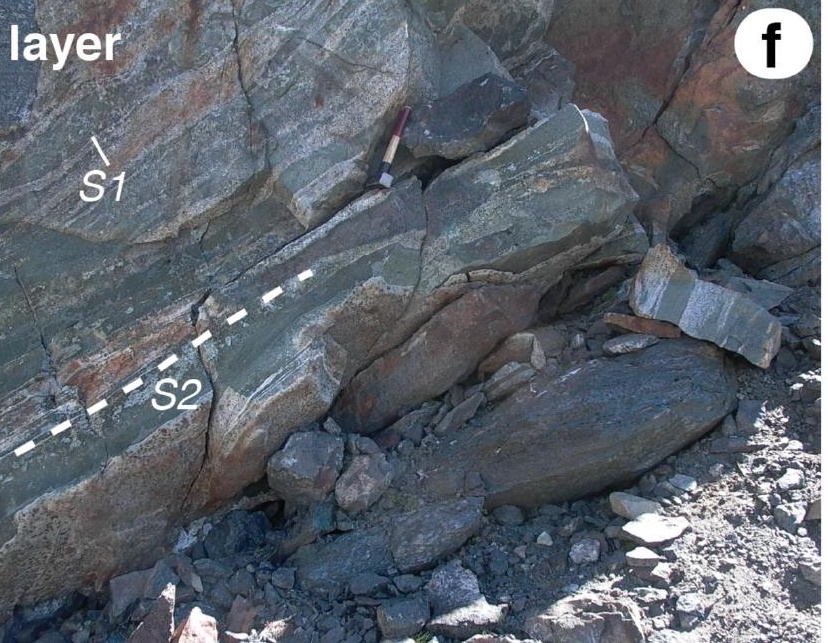
Figure 5. 
Figure 6. 

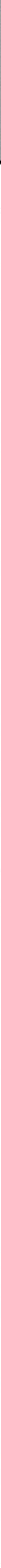
Figure 7. 

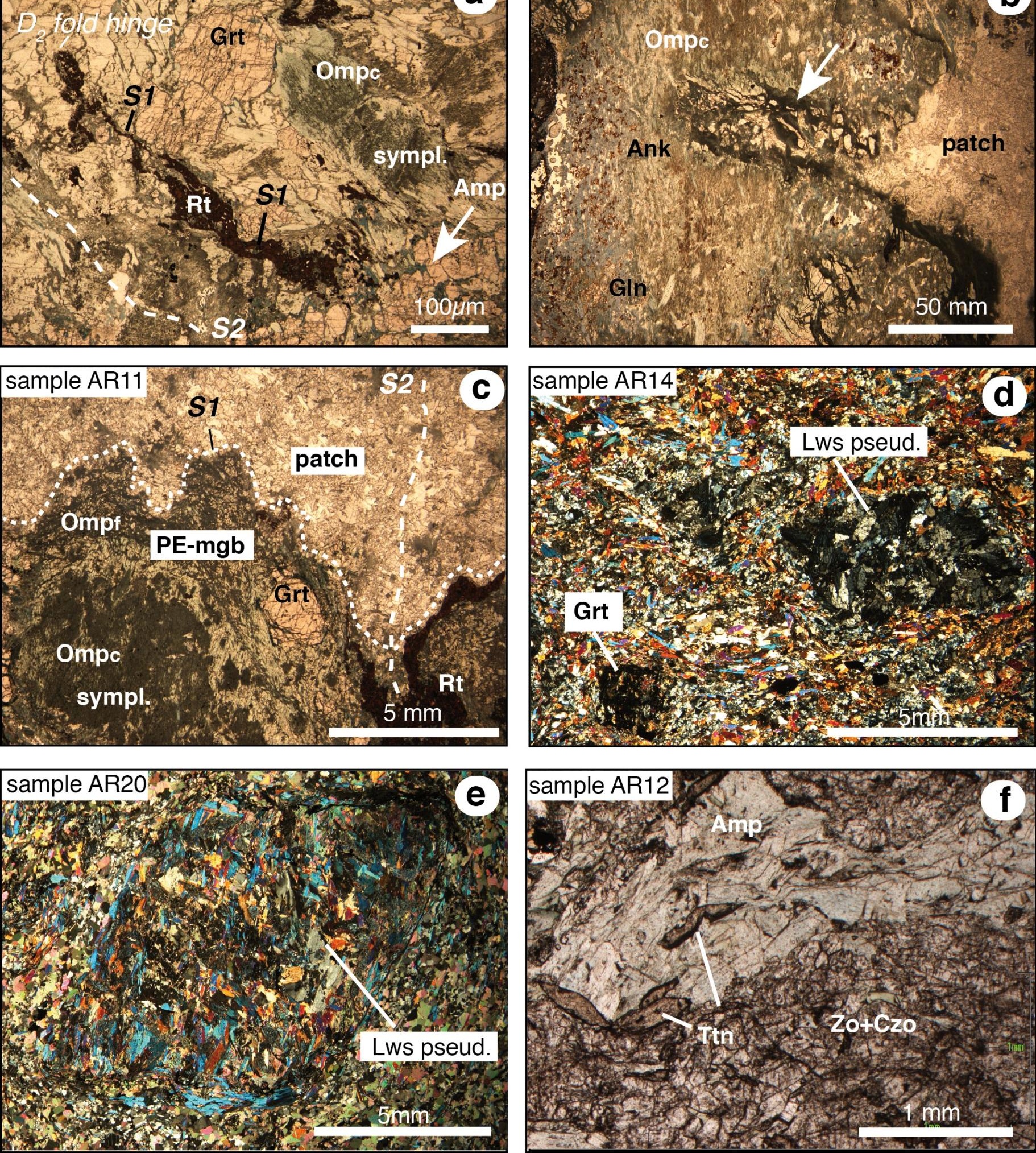
Figure 8. 
Figure 9. 


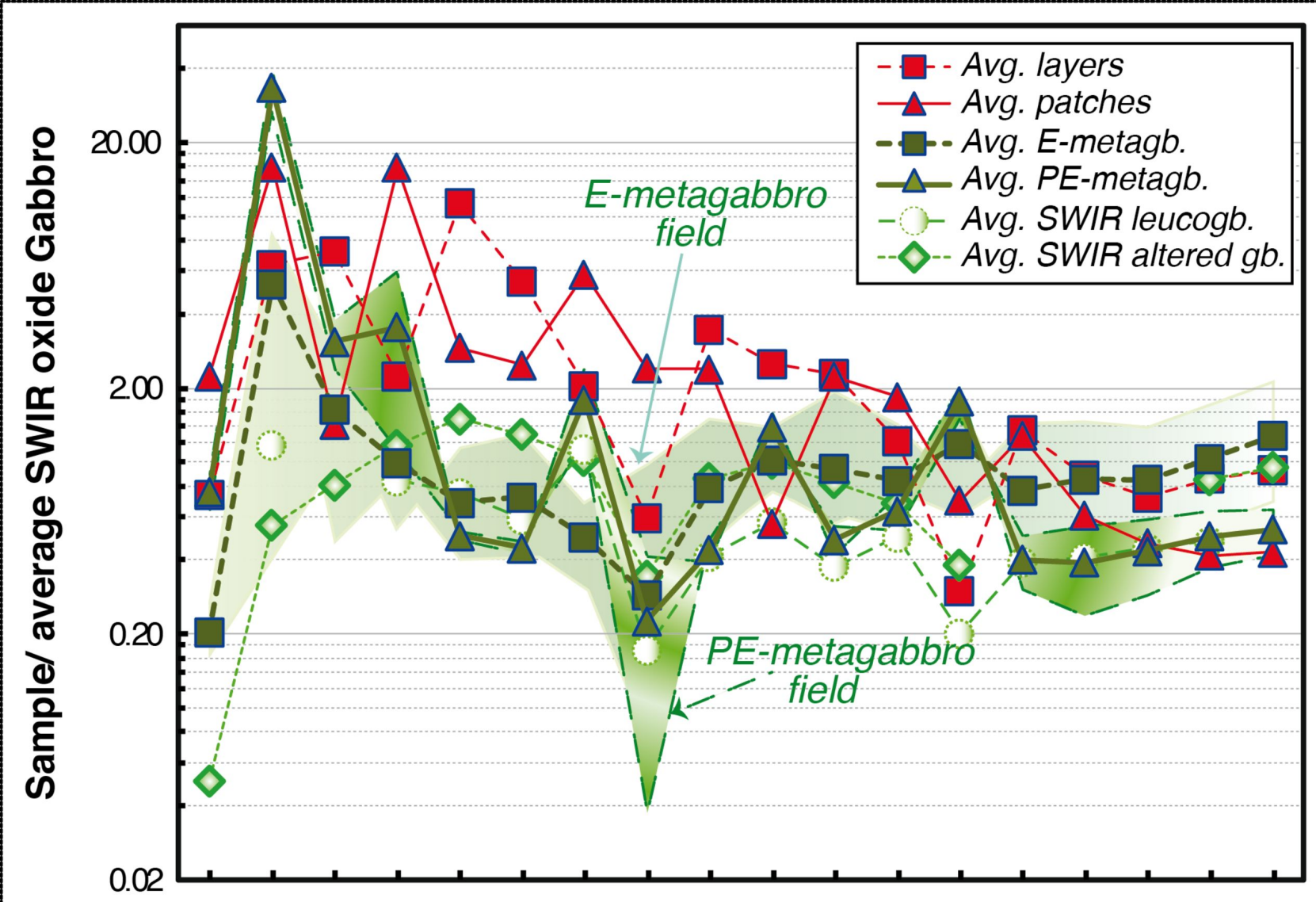

Rb Ba $\mathrm{Nb}$ K La Ce $\mathrm{Sr}$ P $\mathrm{Nd}$ Zr Sm Eu Ti Gd Dy Er Yb Lu 
Figure 10. 


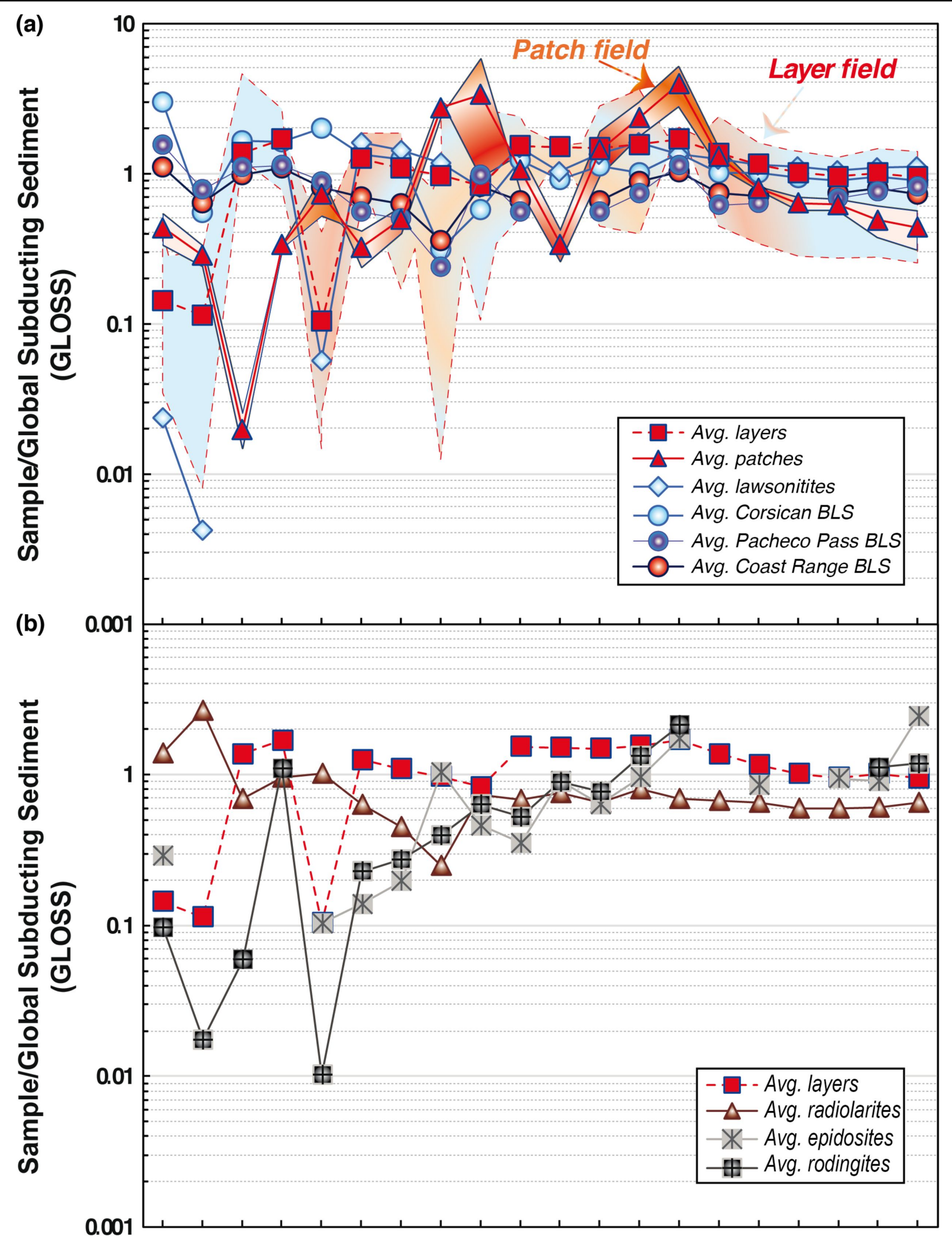

Rb Ba Th Nb K La Ce Sr P Nd Zr Sm Eu Ti Gd Dy Y Er Yb Lu 
Figure 11. 
